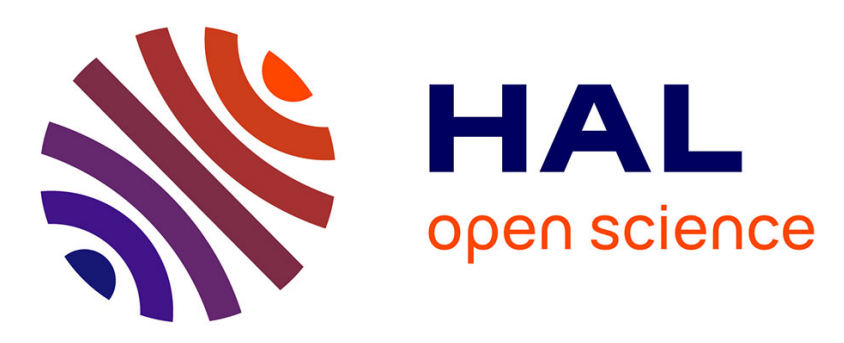

\title{
Flooding effect on mineralogical and geochemical changes in alkaline-sodic soil system of northern Pantanal wetlands, Brazil
}

J. C Oliveira Junior, G. R P Andrade, Laurent Barbiéro, S. A. C. Furquim, P. Vidal-Torrado

\section{To cite this version:}

J. C Oliveira Junior, G. R P Andrade, Laurent Barbiéro, S. A. C. Furquim, P. Vidal-Torrado. Flooding effect on mineralogical and geochemical changes in alkaline-sodic soil system of northern Pantanal wetlands, Brazil. European Journal of Soil Science, 2019, 10.1111/ejss.12871 • hal-02263381

\section{HAL Id: hal-02263381 \\ https://hal.science/hal-02263381}

Submitted on 4 Aug 2019

HAL is a multi-disciplinary open access archive for the deposit and dissemination of scientific research documents, whether they are published or not. The documents may come from teaching and research institutions in France or abroad, or from public or private research centers.
L'archive ouverte pluridisciplinaire HAL, est destinée au dépôt et à la diffusion de documents scientifiques de niveau recherche, publiés ou non, émanant des établissements d'enseignement et de recherche français ou étrangers, des laboratoires publics ou privés. 


\title{
Flooding effect on mineralogical and geochemical changes in alkaline-sodic soil system of northern Pantanal wetlands, Brazil
}

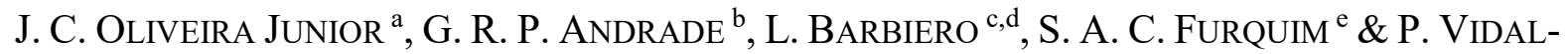 \\ TORRADO ${ }^{\text {f }}$ \\ ${ }^{a}$ Soil and Engineering Department, Federal University of Parana, 80.035-050, Curitiba - Brazil, \\ ${ }^{\mathrm{b}}$ Soil Laboratory, Universidade Estadual do Norte Fluminense Darcy Ribeiro, 28013-602, Campos \\ dos Goytacazes - Brazil, ' Géoscience Environnement Toulouse, Toulouse, 31400, France, \\ ${ }^{\mathrm{d}}$ Laboratório de Ecologia Isotópica, Centro de Energia Nuclear na Agricultura, University of São \\ Paulo, 13416-000, Piracicaba - Brazil, ' Departamento de Ciências Ambientais, Federal University \\ of São Paulo, 09913-030, Diadema-Brazil, ${ }^{\mathrm{f}}$ Department of Soil Science, University of São Paulo, \\ Piracicaba-Brazil.
}

Correspondence: J. Oliveira Junior. E-mail: calderari@ufpr.br.

\section{Running title: Mineralogical changes in alkaline-sodic soil}

\begin{abstract}
Summary
In the northern Pantanal wetlands of Brazil, alkaline sodic soils play a significant role in the ecological functioning of the region, but little is known about their mineralogical equilibria in current flooding dynamics which is necessary for good management of these areas. This study focused on a transition between sodic and non-sodic soils, identified by low frequency electromagnetic induction survey. Samples of B horizons from alkaline-sodic and non-sodic soils were analyzed via soil solution from saturated paste, decomposition of X-ray diffraction (XRD) patterns and Transmission Electron Microscopy with X-ray dispersive energy spectroscopy (TEM-EDS) analysis. The transition between alkaline-sodic and non-sodic soils matches with the transition between flooded and non-flooded areas. The soil solution shows a concentration factor of about 40 along this transition. The formation of sodic soils results from an accumulation by evaporation of solutions with a positive calcite residual alkalinity ( $\mathrm{RA}_{\text {calcite }}$ ), probably imposed by the chemistry of the São Lourenço River. An increasing $\mathrm{Na}: \mathrm{Ca}$ ratio caused solonization of the exchange complex. These alkaline-sodic soils, however, can be interpreted as declining soils in the current context with an evacuation of soluble salts during flood cycles. The detailed investigation of the fine clay fraction $(<0.2 \mu \mathrm{m})$ using full profile modelling and decomposition of XRD patterns and TEM-EDS analysis demonstrates gradual transformations of trioctahedral to dioctahedral smectite by $\mathrm{Mg}$ - Al substitutions on octahedral sites, leading to the prevalence of kaolinite-smectite interstratified minerals when the conditions become more acidic via solodization process.
\end{abstract}

Keywords: tropical soils, solonetz, X-ray modeling, trioctahedral smectit, kaolinite-smectite interstratified, clay mineralogy

\section{Highlights}

1) Clay minerals of alkaline-sodic soil have been altered due to flooding dynamic

2) Clay minerals are a useful tool for understanding environmental changes

3) Interstratified clay minerals result from current acidification

4) The evolution of soil mineral suite is related to the environmental changes

\section{Introduction}


Wetlands ecosystems have a direct relationship with fauna, flora and abiotic components, such as sediments and soil mineralogy (Junk et al., 2014). Because of their high sensitivity to environmental changes, wetland soil attributes are used for paleoenvironmental reconstruction studies (McGlue et al., 2012), including organic matter and clay minerals (Humphries et al., 2010; Pal, 2017; Balestra et al., 2019; Corredo et al., 2019).

In the Pantanal of Brazil, referred as the largest wetland of the world (Por, 1995), evapotranspiration rates slightly exceed rainfall, and the ionic composition of waters locally depends more on the hydrological network connections and groundwater flows (Barbiero et al., 2008). An important geochemical feature resulting from high evaporation rates is presence of the alkaline (sodic) soil systems, rich in magnesium $(\mathrm{Mg})$-rich smectite and iron (Fe)-rich mica, very common around alkaline lakes of the Nhecolândia region (Furquim et al., 2008, 2010a, 2010b, Barbiero et al., 2016). Similar patterns of alkaline evolution have also been described in wetlands of Europe (Armenteros et al., 1995), southern Africa (Deocampo, 2005; Humphries et al., 2010), south-eastern Australia (Reid \& Mosley, 2016) and California (Lee et al., 2004; Graham and O'Geen, 2010). However, the chemical composition of water in the Pantanal varies widely, from saline to alkaline (Rezende Filho et al., 2012), and how this impacts the soil mineralogy of Northern Pantanal is not well known.

The soil distribution in the Northern Pantanal is closely associated with the landscape. At the highest altitudes (paleolevees), Natrustalfs, with a Bt horizon and high exchangeable sodium percentage (ESP) values prevail; in the lowest altitudes (floodable areas) Plinthaquults are more common, whereas Quatzipsamments occur in the paleo-channels (Nascimento et al., 2015; Oliveira Junior et al., 2017a, 2017b). Soils with high ESP and carbonate precipitates have been observed in the highest ground (approximately $3 \mathrm{~m}$ above the floodplain) that originated from these elongated paleolevees (Nascimento et al., 2013; Oliveira Junior et al., 2017a, 2017b), but little is known about their mineralogical characteristics.

The sodic soils of the northern Pantanal play an important ecological role. The most clayey materials are ingested by many local (birds and mammals) in a process known as geophagy (Coelho, 2016). In addition, these soils support specific vegetal species whose fruits are part of the diet of endangered species, such as the blue macaw (Anodorhynchus hyacinthinus). The management of these sodic soils for various purposes in a natural floodplain as Pantanal requires a better understanding of their origin, conditions of formation and current dynamics, information that is lacking for the northern region.

A detailed study of the solid and liquid phases of the soil is essential to distinguish clay minerals produced by contemporary weathering or precipitation by fluids from those resulting from past environmental settings and diagenesis, which are no longer in equilibrium with the soil solution (AlDroubi et al., 1980; Humphries et al., 2010; Joeckel and Ang Clement, 2005; Shoba and Sen'kov, 2011). In the soil environment, the mineral transformations are driven by the meteoric waters, sometimes altering the mineral suites at very short distances (Barbiero et al., 2016; Oliveira Junior et al., 2014), providing indicators for environmental changes (Deocampo, 2005; Humphries et al., 2010; Pal, 2017), and usually involving the formation of interstratified clay minerals (Furquim et al., 2008; Furquim et al., 2010a, 2010b).

Based on previously reported morphological, chemical and hydrological evidence (Oliveira Junior et al., 2019), this study aims to characterize the geochemical pathway and the clay mineral assemblage $(<0.2 \mu \mathrm{m}$ fraction) of a soil system evolving from former alkaline conditions to more acidic current conditions. We test the hypothesis that the soil solution geochemical changes drive transformations in the clay mineral assemblage, themselves induced by the modern water regime and by different climatic settings.

\section{Materials and methods}

Study site

The present study was carried out in the Northern Pantanal, in the Private Natural Heritage Reserve (RPPN) belonging to the Pantanal Social Service of Commerce (SESC) in the district of 


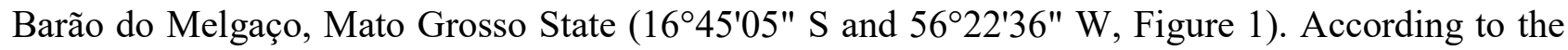
Köppen classification, the climate is Aw (Por, 1995), with monthly average temperatures ranging from 22 to $32{ }^{\circ} \mathrm{C}$. Mean annual rainfall is $1,100 \mathrm{~mm}$ and the potential evapotranspiration is $1,400 \mathrm{~mm}$, resulting in an annual water deficit of about $300 \mathrm{~mm}$. Maximum flooding occurs from January to April, reaching $4.5 \mathrm{~m}$ above the normal river level, as a consequence of low local declivity and a large volume of water from the surrounding plateaus.
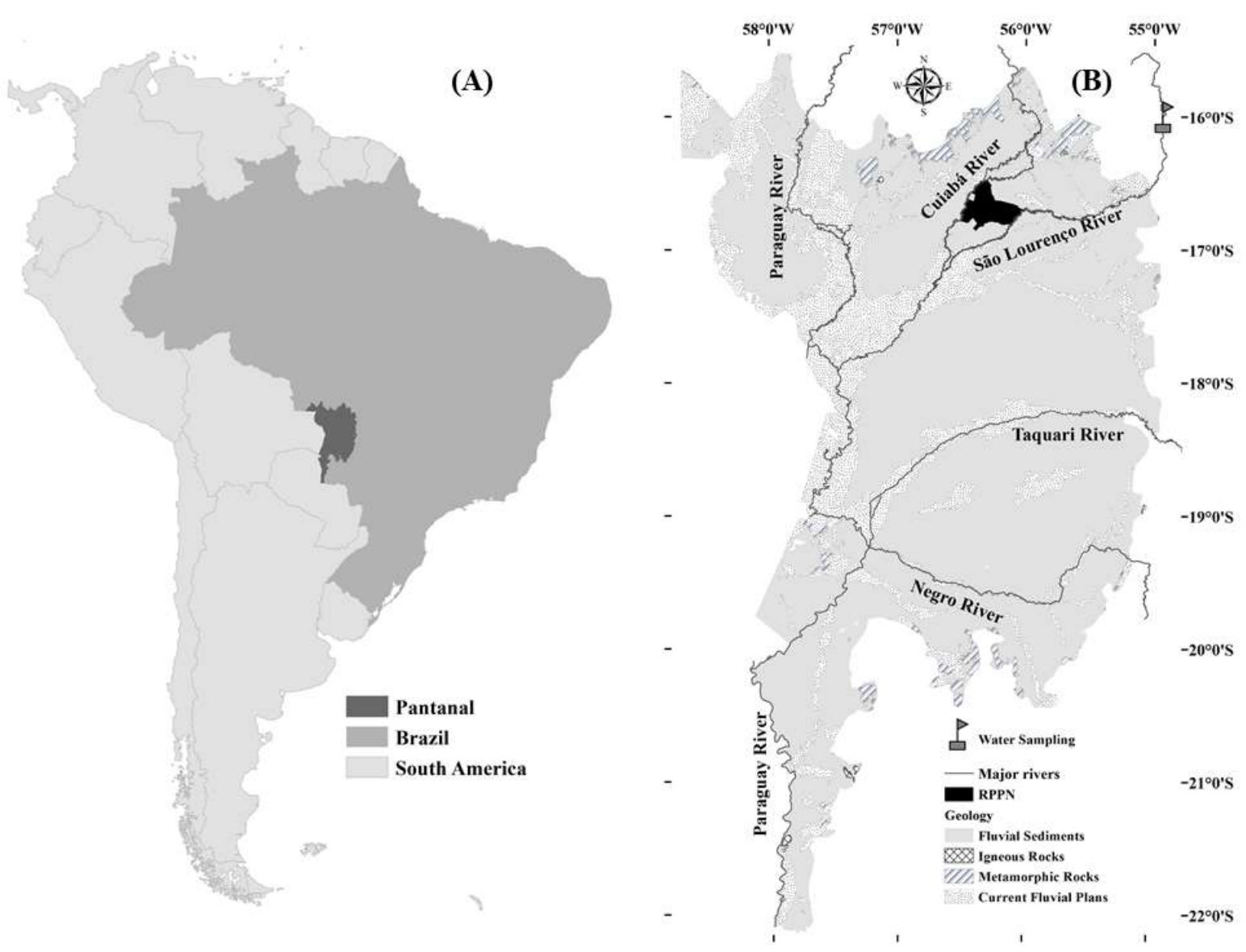

Figure 1. South America (light gray), Brazil (medium gray) and Brazilian Pantanal (dark gray - A). Detail of the Private Natural Heritage (RPPN) bordered by Cuiabá and São Lourenço River, and geological setting in Brazilian Pantanal (B).

The Pantanal Basin is a huge tectonic depression filled by $\sim 550 \mathrm{~m}$ thick layers of siliciclastic sediments (in contact with the Pre-Cambrian continental basement below) with a broad range of grain-size distribution. These sediment layers comprise the Pantanal formation, deposited by eolian and fluvial processes since the Pliocene. The sediments are currently deposited by the tributaries of Paraguay River, incoming from several lithologies that surround the Pantanal Basin (Figure 1). The upper sedimentary sequences, with Pleistocenic and Holocenic ages, also have a varying grain-size distribution, and whose deposition was affected by climatic variations in the last 120,000 years (Assine and Soares, 2004). These layers are in contact with the boundaries of soil horizons (up to 2 $\mathrm{m}$ deep), differentiated by pedogenic processes. In the São Lourenço River fan, where this study was performed, the layers overlying soil horizons were dated at 31,000-47,000 years BP and are essentially coarse-textured at the base of soils developed over paleo-channels, paleo-levees and mounds, the most common geomorphic features of the area (Nascimento et al., 2013).

The lithology of the São Lourenço Rivers Basin mainly consists of Parana Basin sandstones, with some areas of limestones and other carbonate-rich rocks. However, these carbonate rocks have little influence on the river chemistry (Rezende Filho et al., 2012; 2015). Therefore, the São Lourenço River water has low electrical conductivity $\left(20\right.$ to $\left.40 \mu \mathrm{S} \mathrm{cm}^{-1}\right)$ but shows positive calcite Residual 
Alkalinity ( $\mathrm{RA}_{\text {calcite), }}$, i.e. higher alkalinity than calcium (Ca) content (Barbiero et al., 2004). Such water, if it evaporates in the soil, may in the long term impose its chemical profile onto the soil solution and cause an increase in $\mathrm{pH}$ and in the proportion of sodium $(\mathrm{Na})$ on the exchange complex. The São Lourenço River supplies the eastern part of the RPPN where the soils are formed from fluvial sandy sediments. The local relief is dominated by paleochannels and paleolevees, situated a few meters above extensive floodplains. The upper parts of paleolevees are not affected by flooding (Nascimento et al., 2013; Oliveira Junior et al., 2019).

\section{Soil surveying and sampling}

To assess the impact of flooding events, a transect comprising the transition between nonflooding and flooding regions of a paleolevee towards a floodplain was considered. A preliminary survey was carried out using electromagnetic induction methods in order to identify the changes of soil electrical conductivity, and to locate the main transitions. We used an EM38 electromagnetic sensor (Geonics Ltd, Ontario, Canada) with vertical dipoles, which gives the apparent Electrical Conductivity $\left(\mathrm{EC}_{\mathrm{a}}\right)$ of the soil $\left(\mathrm{mS} \mathrm{m}^{-1}\right)$, over a depth of about $1.7 \mathrm{~m}$. Based on the largest $\mathrm{EC}_{\mathrm{a}}$ variations obtained, soil features were observed by manual soil auger, and $\mathrm{pH}$ and $\mathrm{EC}$ were measured every $0.2 \mathrm{~m}$ in depth. A $6 \mathrm{~m}$ long and $2 \mathrm{~m}$ deep trench was then excavated over the area with major $\mathrm{EC}$ and $\mathrm{pH}$ variations. Soil color, texture, structure, porosity, and other pedological features (nodules, etc.) have been described by Oliveira Junior et al. (2019). A field test for the occurrence of calcite was performed using $10 \% \mathrm{HCl}$. Soil samples were collected from a lateral side of the trench along a regular $0.25 \times 0.25 \mathrm{~m}$ grid, comprising 121 samples. The results for soil exchangeable complex characterization, $\mathrm{pH}$, micromorphology and particle size distribution are reported by Oliveira Junior et al. (2019).

\section{Soil chemistry - saturated extracts}

Saturated extracts were obtained from each soil sample by adding deionized water and equilibrating the soil with the solution for 5 hours at $25^{\circ} \mathrm{C}$, considering this time sufficient to approach the equilibrium whilst limiting microbial development that may alter the chemical composition of water. The solutions were extracted under vacuum (Pansu and Gautheyrou (2006)). Anions (chloride $\left(\mathrm{Cl}^{-}\right)$, sulphate $\left(\mathrm{SO}_{4}{ }^{2-}\right)$, fluoride $\left(\mathrm{F}^{-}\right)$, nitrate $\left(\mathrm{NO}_{3}{ }^{-}\right)$, nitrite $\left(\mathrm{NO}_{2}{ }^{-}\right)$, and phosphate $\left(\mathrm{PO}_{4}{ }^{3-}\right)$ and cations $\left(\mathrm{Na}^{+}\right.$, potassium $\left(\mathrm{K}^{+}\right), \mathrm{Ca}^{2+}, \mathrm{Mg}^{2+}$, ammonium $\left(\mathrm{NH}_{4}^{+}\right)$) were analyzed by High Pressure Liquid Chromatography (Dionex ICS-90). Carbonate $\left(\mathrm{CO}_{3}{ }^{2-}\right)$ alkalinity was measured by acid titration.

The $\mathrm{Na}^{+}$ion is generally present in the soil solution at concentrations high enough to be accurately quantified, and it interacts little with the solid phases. Consequently, it is frequently used as a conservative element to evaluate the concentration factor of the solution (Barbiero et al., 2008). The concentration factor $(\mathrm{CF})$ was therefore defined as:

$$
\mathrm{CF}_{\mathrm{i}}=[\mathrm{Na}]_{\mathrm{i}} /[\mathrm{Na}]_{0}
$$

Equation 1

in which $[\mathrm{Na}]_{i}$ denotes the $\mathrm{Na}$ concentration of a given water sample " $\mathrm{i}$ " and $[\mathrm{Na}]_{0}$ the lowest $\mathrm{Na}$ concentration observed in the soil extract dataset, whatever the unit.

\section{River water sampling}

Because the São Lourenço river water is suspected to have imposed its chemistry on the soil, two samples were collected in order to characterize its chemical composition. Samples were taken in the middle of the stream during 2013 [rainy season (February) and dry season (September)] on the plateau, just upriver from the Pantanal border (coordinates $15^{\circ} 59^{\prime} 51.81^{\prime \prime} \mathrm{S}, 5^{\circ} 55^{\prime} 21.30^{\prime \prime} \mathrm{W}$ ). These water samples were filtered in the field $(0.45 \mu \mathrm{m}$ cellulose acetate syringe filters $)$ and stored in Highdensity polyethylene (HDPE) containers in cool and dark conditions until analysis $\mathrm{pH}$ and $\mathrm{EC}$ were measured in the field in a portion of the filtrate.

\section{Mineralogy}


Two samples were selected from the B horizons in contrasting situations: those in the nonflooded area with calcite precipitations (Btk), and those in the seasonally flooded area (Bt2). These two horizons were considered for mineralogical investigations because of their contrasting geochemical attributes, such as EC, $\mathrm{pH}$ and cation exchange capacity (CEC) (Oliveira Jr. et al., 2019). The Btk horizon shows a basin shape, hampering ion leaching, whereas the Bt 2 horizon is gently inclined towards the floodplain, thus favoring ion leaching.

The samples were air dried, ground and sieved $(<2 \mathrm{~mm})$. The organic matter was removed using hydrogen peroxide $\left(\mathrm{H}_{2} \mathrm{O}_{2}\right)(15 \%$, v/v) and the Fe-oxyhydroxides by the sodium citrate-bicarbonatedithionite $(\mathrm{CBD})$ treatment. The clay fraction $(<2 \mu \mathrm{m})$ was separated from the sand and silt fractions after sieving and sedimentation process in a mild alkaline solution.

The sand fraction was sieved $(<0.05 \mathrm{~mm})$ and after the chemical dispersion using $\mathrm{Na}_{2} \mathrm{CO}_{3}$, the silt fraction was separated from the clay fraction according to the time calculated using Stoke's law. The suspension containing silt + clay fractions was put into a $1 \mathrm{~L}$ beaker and the clay was siphoned several times until the suspension was clear. The clay fraction $(<2 \mu \mathrm{m})$ was the separated into two sub-fractions, the $2-0.2 \mu \mathrm{m}$ and $<0.2 \mu \mathrm{m}$ fractions (coarse and fine clay fractions, respectively), and only the later was investigated in this study. The separation was carried out after successive centrifugations $(5,070 \mathrm{~g}, 21 \mathrm{~min}, 25-30$ times $)$, until the supernatant containing the $<0.2 \mu \mathrm{m}$ fraction was clear. The collected supernatant containing the fine clay fraction was stored in plastic bottles and flocculated using $1 \mathrm{M} \mathrm{MgCl}_{2}$ solution. The $\mathrm{Mg}$-saturated samples were dispersed using an ultrasonic tip and pipetted onto glass slides, to be studied as oriented mounts in the X-ray diffraction (XRD) device. They were studied as air dried (at room temperature) and glycolated samples, after solvation in a saturated atmosphere $\left(60^{\circ} \mathrm{C}, 16 \mathrm{~h}\right)$. X-ray diffraction analyses were carried out in a Rigaku Miniflex II device at $30 \mathrm{kV}$ and $10 \mathrm{~mA}$, with copper $(\mathrm{Cu})(\mathrm{CuK \alpha})$ radiation, graphite monochromator, Soller slits of $5.5^{\circ}$ and $2.5^{\circ}$ and slit divergent of $0.1^{\circ}$. Oriented patterns were studied from 3 to $35^{\circ} 2 \theta$, with a step-scan of $0.01^{\circ} 2 \theta$ and scan speed of $5 \mathrm{~s} / \mathrm{step}$. Non-oriented XRD patterns were scanned from 59 to $63^{\circ} 2 \theta$ for the study of 060 peak, with step size of $0.02^{\circ} 2 \theta$ and low scanning speed of 55 $\mathrm{s} / \mathrm{step}$, in order to improve the peaks signal-to-noise ratio and to maximize their intensity.

\section{Modelling of XRD patterns modelling and 060 peak fitting}

The XRD patterns of glycolated samples were modelled using the software NEWMOD 3.2.1, which allows for simulating the distribution and crystal chemical attributes of endmembers and interstratified clay minerals (Reynolds and Reynolds, 1996). The following parameters were simulated: the position of the 001 peaks, the octahedral Fe content (on $\mathrm{O}_{10}\left[\mathrm{OH}_{2}\right]$ basis for 2:1 minerals and $\mathrm{O}_{5}[\mathrm{OH}]_{4}$ basis for 1:1 minerals), $\mathrm{K}$ in the illite interlayer, the average and maximum number of layers per coherent domain ( $\mathrm{N}_{\text {mean }}$ and $\mathrm{N}_{\max }$ parameters), and the final proportion (wt. \%) of each mineral.

The experimental 060 peaks were mathematically decomposed and calculated individual components fitted into the experimental pattern using the program GRAMS/AI (Thermo Fisher Scientific ${ }^{\mathrm{TM}}$ Waltham, MA, US) in order to identify the occurrence of a di- or tri-octahedral clays. The decomposition of the experimental curves was performed by adding curves with Gaussian shape. The position of each maximum was used to identify the occupation of di- or tri-octahedral sites and each curve area was used to estimate their proportion in the samples (Deocampo et al., 2009).

\section{Transmission electron microscopy with X-ray dispersive energy spectroscopy (TEM-EDS).}

The chemical composition of individual crystals of the $<0.2 \mu \mathrm{m}$ fraction was determined using transmission electron microscopy with microanalysis by X-ray dispersive energy spectroscopy (TEM-EDS). A small aliquot of the $<0.2 \mu \mathrm{m}$ fraction of each B horizon was diluted in ultrapure water, deposited onto a $\mathrm{Cu}$ grid on the top of a graphite film and air dried. The samples were studied by a TEM Phillips CM-200 device, under tension of $180 \mathrm{kV}$. Approximately 20 crystals of each sample from the B horizons of each soil were analyzed by an Element EDS System (EDAX Inc., Manhwa, NJ, USA). The recorded chemical composition (wt. \% basis) was corrected by using mineral standards (estimated error between 10 and 15\%). 
Mineral formulas were calculated according to the procedure described in Moore and Reynolds (1997), balancing the negative charge caused by isomorphic substitutions in tetrahedral and octahedral sites with the interlayer cations positively charged. The crystals assigned as K-S (intermediary composition between smectite and kaolinite) were normalized on $\mathrm{O}_{10}(\mathrm{OH})_{2}$ basis (Cuadros et al., 2009), representing the half unit formula of 2:1 clay structure. This normalization does not consider the half unit cell formula of kaolinite, based on $\mathrm{O}_{5}(\mathrm{OH})_{4}$ anions, but it is the only possible way to distribute cation in the K-S structure.
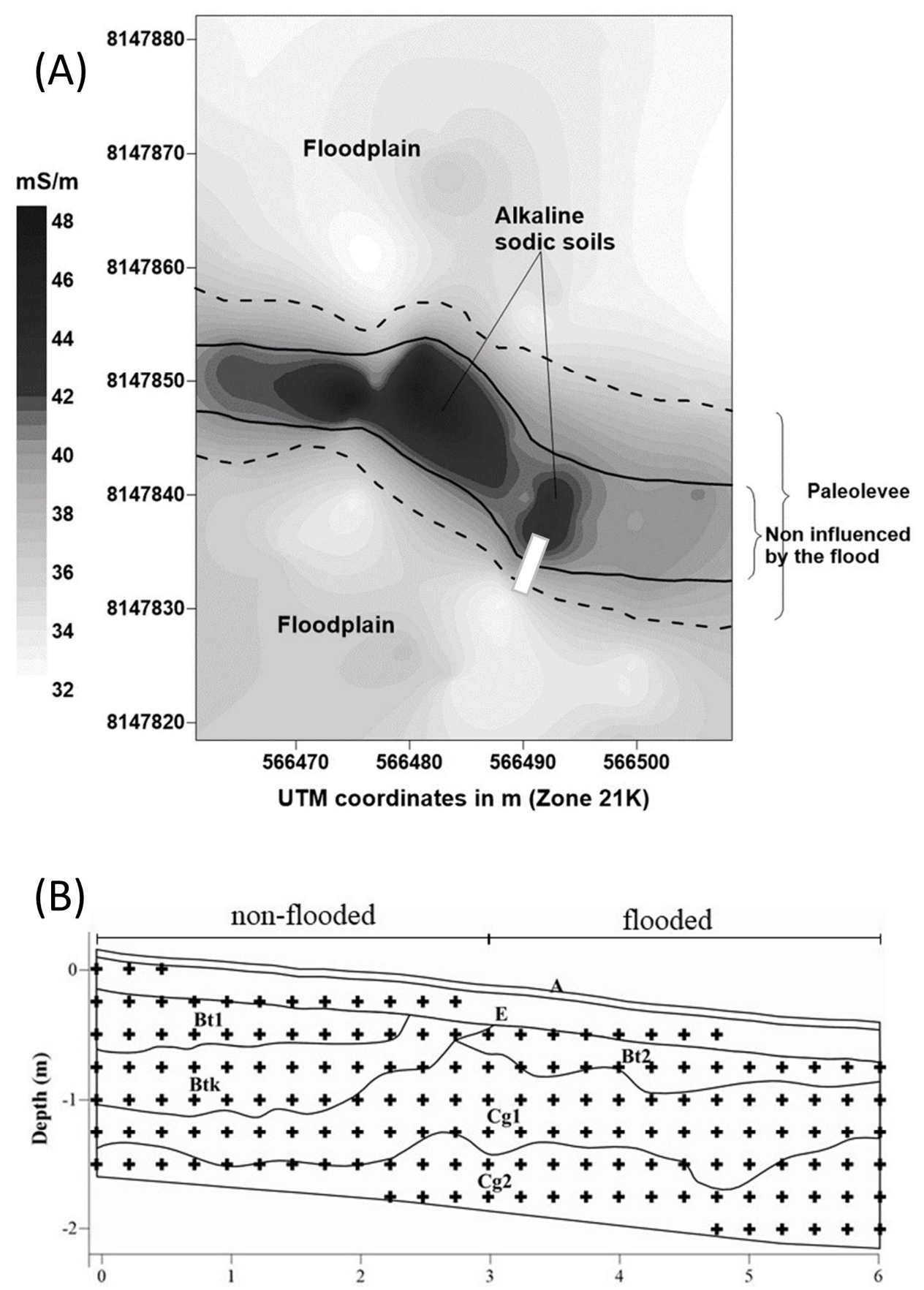

Figure 2. Apparent electrical conductivity $\left(\mathrm{EC}_{\mathrm{a}}\right)$ obtained by $\mathrm{EM} 38(\mathrm{~A})$. The white bar indicates the location of the trench. In detail non-flooded and flooded zone, with distribution of the horizons along the trench. "+" denote sampling points for saturated extract (B). 


\section{Results}

$E C_{a}$ survey, saturated extracts and water samples

The $\mathrm{EC}_{\mathrm{a}}$ ranged from 32 to $36 \mathrm{mS} \mathrm{m}^{-1}$ in the floodplain area and increasing from 40 to $50 \mathrm{mS} \mathrm{m}^{-}$ ${ }^{1}$ at the border of the paleolevee (Figure 2A). Based on ECa values, the transition between paleoleveefloodplain was abrupt and matched with the limit of influence of the seasonal floods (Figures 2B). The $\mathrm{pH}$ is higher in the horizon assigned as Btk (Figure 3), in the highest elevation of the trench, reaching values close to 9.0 while in the floodplain presented the lowest $\mathrm{pH}$ values, close to 4.5 (Oliveira Junior et al., 2019).
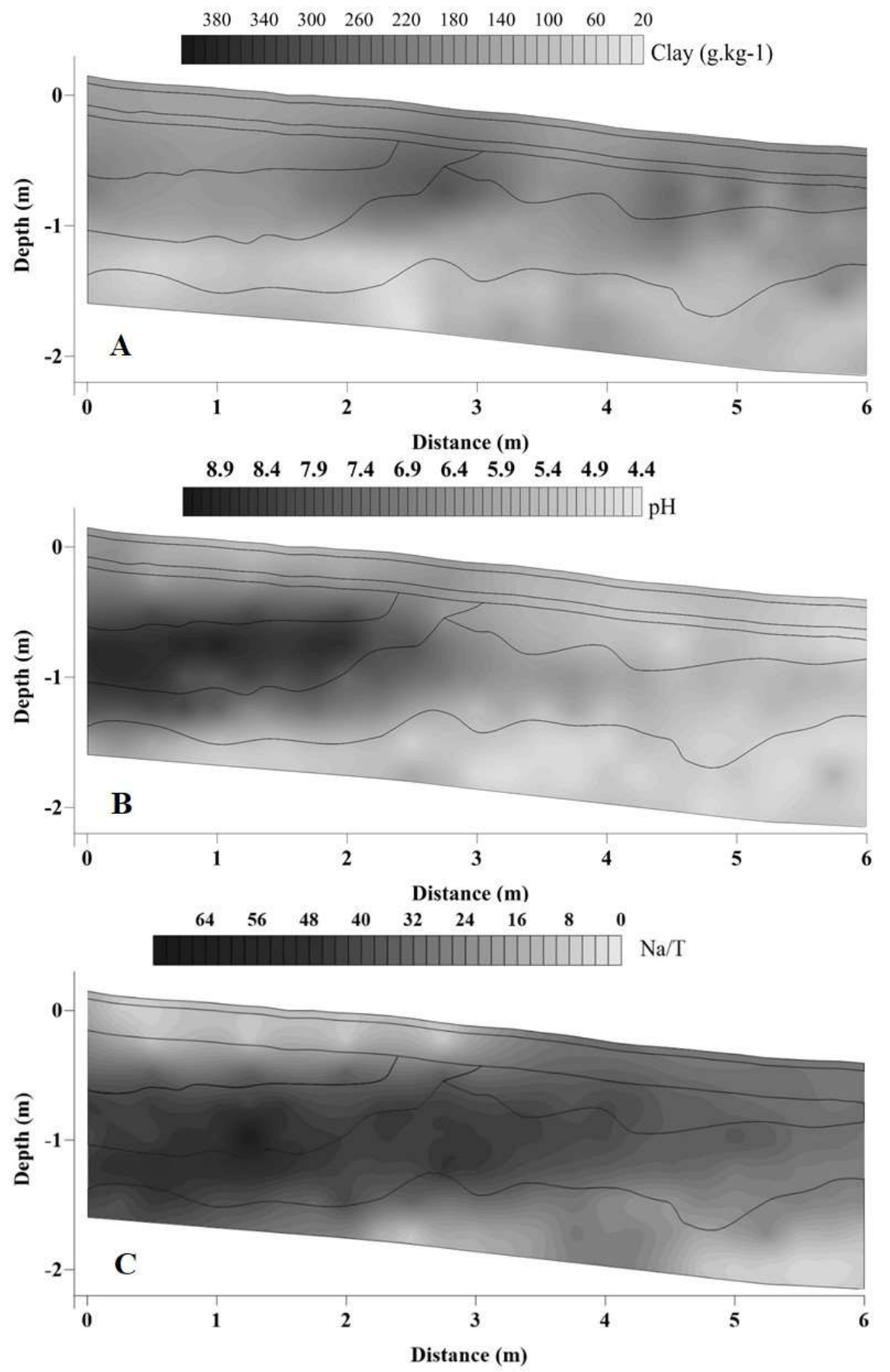

Figure 3. Spatial distribution of clay contents (A), $\mathrm{pH}(\mathrm{B})$ and exchangeable sodium percentage (ESP $-\mathrm{C}$ ) along the trench opened in the paleolevee-floodplain transition. Solid lines represent the horizons limits. 


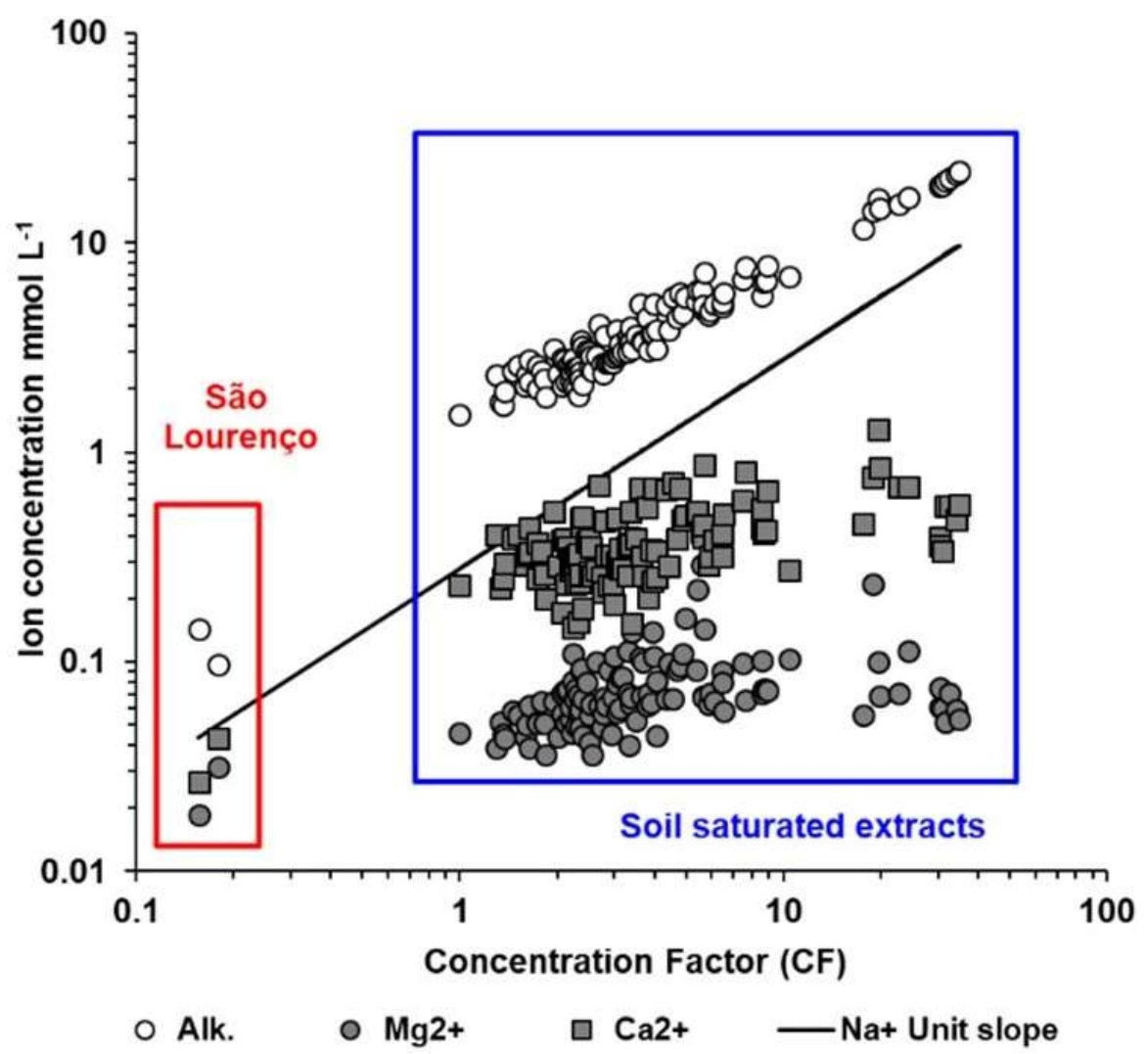

Figure 4. Concentration diagram for carbonate alkalinity $\left(\mathrm{HCO}_{3}{ }^{-}+\mathrm{CO}_{3}{ }^{2-}\right)$, sodium, calcium and magnesium in the soil solution, obtained from São Lourenço water samples and soil saturated extracts. The concentration factor $\mathrm{CF}$ is based on the relative sodium content (see equation 1).

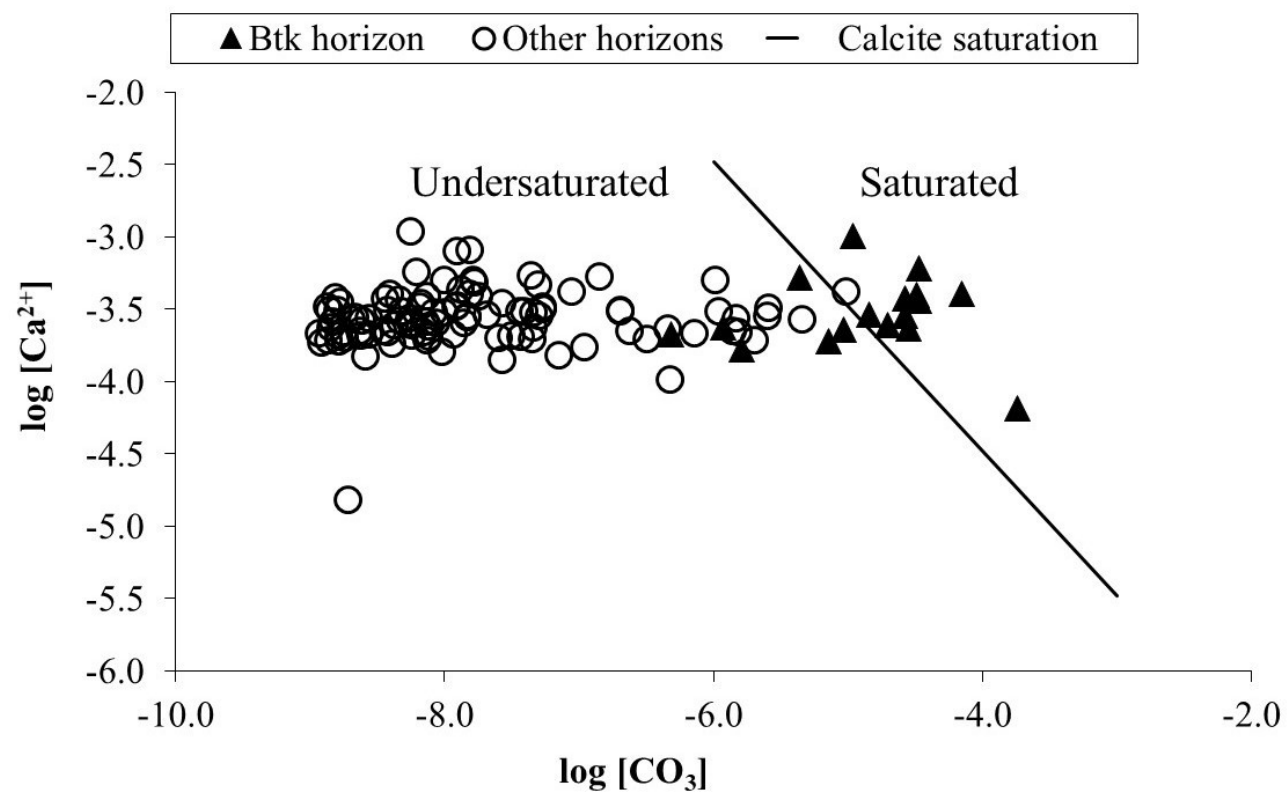

Figure 5. Calcite stability diagram with points above the line indicating supersaturated samples and points below the line indicating subsaturated samples.

The main chemical changes in saturated extracts along the trench are plotted in Figure 4. The concentration factor (CF) range was about 40 with $\mathrm{Na}^{+}$concentrations, from $0.27 \times$ to $9.71 \mathrm{mM}$. Alkalinity increased, but slightly less than the Na contents in the most concentrated solutions. On the other hand, the $\mathrm{Mg}$ and $\mathrm{Ca}$ contents increase up to a $\mathrm{CF}$ of about 5 , then remained the same until $\mathrm{CF}$ about 15 , and then showed a decreasing trend for the highest $\mathrm{CF}$ values. Chloride and $\mathrm{SO}_{4}{ }^{2-}$ 
concentrations (not plotted) were much lower and showed a dispersion trend in relation to $\mathrm{Na}$ (maximum values of 1.09 and $0.27 \mathrm{mg} \mathrm{L}^{-1}$ for $\mathrm{Cl}$ and $\mathrm{SO}_{4}{ }^{2-}$, respectively). São Lourenço water samples were less mineralized, but revealed a similar chemistry, with the following ionic content order: Alk. $>\mathrm{Na}^{+}>\mathrm{Ca}^{2+}>\mathrm{Mg}^{2+}$. The proportions of $\mathrm{Mg}^{2+}$ were slightly higher than those determined in the soil extract. Both the river water and the soil solution showed a positive $\mathrm{RA}_{\text {calcite. The less }}$ mineralized extracts were collected from horizons A, E and the Cg2 near the floodplain. The Btk was the most mineralized horizon, with soil extracts slightly supersaturated with respect to calcite (Figure 5) and a $\mathrm{Na}-\mathrm{HCO}_{3}$ chemical profile. The higher mineralization of the soil solutions was accompanied by an increase in $\mathrm{pH}$ that reached values close to 9.5 in the Btk horizon.

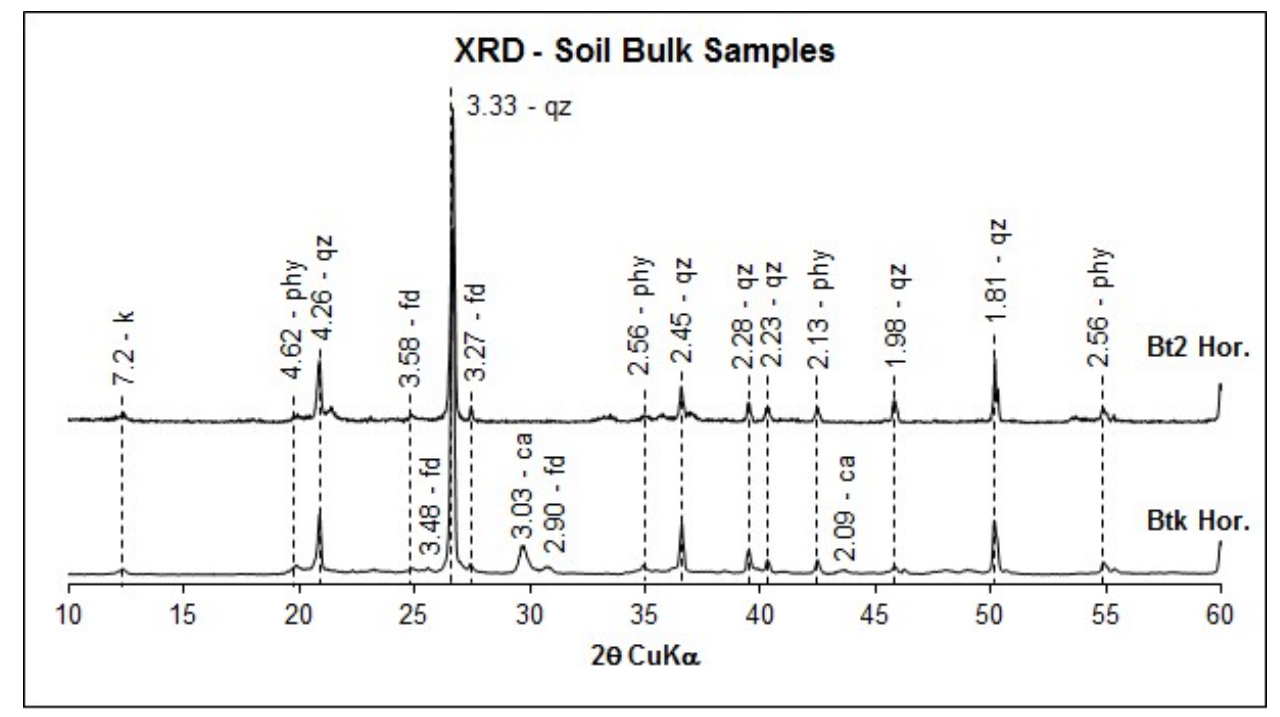

Figure 6. XRD patterns of soil bulk samples from $\mathrm{Bt} 2(\mathrm{~A})$ and $\mathrm{Btk}(\mathrm{B})$ horizons. The d-space values associated to peak maxima are in $\AA\left(10^{-10} \mathrm{~m}\right)$ (qz - quartz; fd - feldspar group minerals; phy phyllosilicates non-basal peaks; ca - calcite).

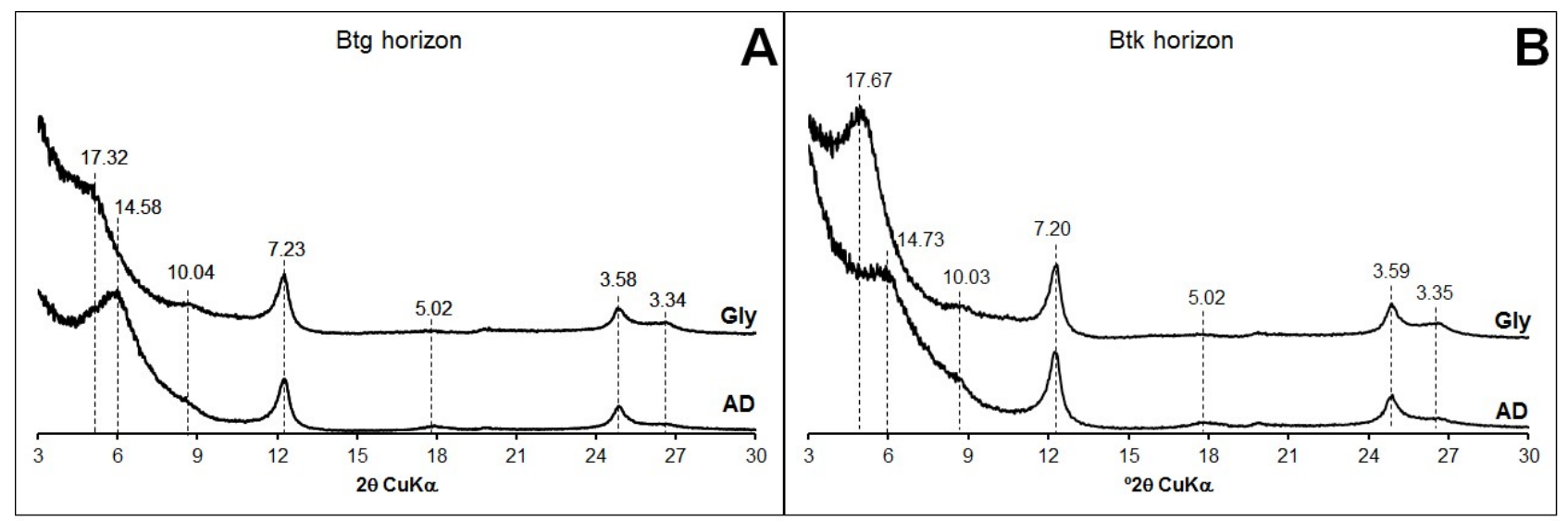

Figure 7. Air-dried (AD) and glycolated (gly) oriented XRD patterns $(<0.2 \mu \mathrm{m}$ fraction, Mgsaturated) of the samples from the two studied soil horizons. The d-space values associated to peak maxima are in $\AA\left(10^{-10} \mathrm{~m}\right)$.

\section{$X$-ray diffraction $(X R D)$}

The XRD patterns of soil bulk samples show the prevalence of quartz, likely restricted to the sand and silt fractions, identified by the most intense and sharp peaks at 4.26, 3.33, 2.45 and 1.81 A. Feldspar group minerals are minor components, identified by a sequence of peaks at $\sim 3.58$ and 3.27 
A. Non-basal peaks of phyllosilicates are also detectable, but as low-intensity and broad peaks. In the sample Btk, calcite peaks were identified at 3.03, 2.28 and 2.09 A d-spaces. This phase occurs as precipitates, confirmed in the soil morphological description in the field by the reaction with diluted hydrochloric acid (HCl) (Oliveira Jr. $2017 \mathrm{ab}$ )

X-ray diffraction patterns of oriented mounts of $<0.2 \mu \mathrm{m}$ fraction revealed the existence of kaolinite, smectite and illite, which yielded distinct peak maxima, in addition to some evidences of the presence of mixed-layered minerals, such as broad asymmetries associated to peak maxima and slight displacements in the position of clay peaks (Moore and Reynolds, 1997) (Figure 7). Calculations using Newmod 3.2.1 (Figure 7) revealed more complex mineral assemblages, in which endmember clays occur together with randomly stacked layers (R0) interstratified minerals (Table 1).

Table 1. Results of XRD modeling performed with NEWMOD 3.2.1 for the $<0.2 \mu \mathrm{m}$ fraction of Bt2 and Btk samples

\begin{tabular}{lcccccccc}
\hline Mineral & \% inter. & Fe kt $^{\mathbf{2}}$ & $\mathbf{F e ~ s m e ~}^{\mathbf{2}}$ & $\mathbf{F e ~ i l l ~}^{\mathbf{2}}$ & $\mathbf{K ~ i l l ~}^{\mathbf{3}}$ & $\mathbf{N}_{\mathbf{m a x}}{ }^{\mathbf{4}}$ & $\mathbf{N}_{\mathbf{M e d}} \mathbf{5}^{\mathbf{5}}$ & $\mathbf{\% ~ f i n a l}^{\mathbf{6}}$ \\
\hline 1A (K-S) & & & $\mathbf{B t 2}$ & & & & & \\
2A (K-S) & $99-1$ & 0.6 & 1.7 & - & - & 30 & 20 & 25 \\
3A (K-S) & $88-12$ & - & 1.7 & - & - & 12 & 7 & 23 \\
4A (K-S) & $50-50$ & 0.7 & 1.7 & - & - & 7 & 1 & 27 \\
5A (Illite) & $15-85$ & - & 1.7 & - & - & 7 & 3 & 8 \\
\hline & - & - & - & 0.2 & 0.8 & 11 & 4 & 17 \\
\hline 1B (K-S) & & & Btk & & & & & \\
2B (K-S) & $99-1$ & 0.6 & 1.7 & - & - & 30 & 20 & 19 \\
3B (K-S) & $88-12$ & - & 1.7 & - & - & 12 & 7 & 28 \\
4B (Illite) & $20-80$ & - & 1.7 & - & - & 7 & 1 & 6 \\
5B (I-K) & - & - & & 0.5 & 0.8 & 12 & 6 & 14 \\
6B (Smectite trioc.) & $53-47$ & - & & 0.5 & 0.8 & 14 & 3 & 14 \\
\hline
\end{tabular}

${ }^{1} \mathrm{Pos}$. \# 1 and \# $2-;{ }^{2} \mathrm{Fe} \mathrm{kt,} \mathrm{Fe} \mathrm{sme.} \mathrm{and} \mathrm{Fe} \mathrm{ill} \mathrm{-} \mathrm{octahedral} \mathrm{Fe}$ in kaolinite, smectite and illite, ${ }^{3} \mathrm{~K}$ illite $-\mathrm{K}$ in the interlayer positions of illitic layers, on the basis of $\mathrm{O}_{10}(\mathrm{OH})_{2} ;{ }^{4} \mathrm{~N}_{\max }$ - maximum number of layers per coherent domain; ${ }^{5} \mathrm{~N}_{\text {mean }}-$ mean number of layers per coherent domain; ${ }^{6}$ final $\%$ : final proportion of each mineral.

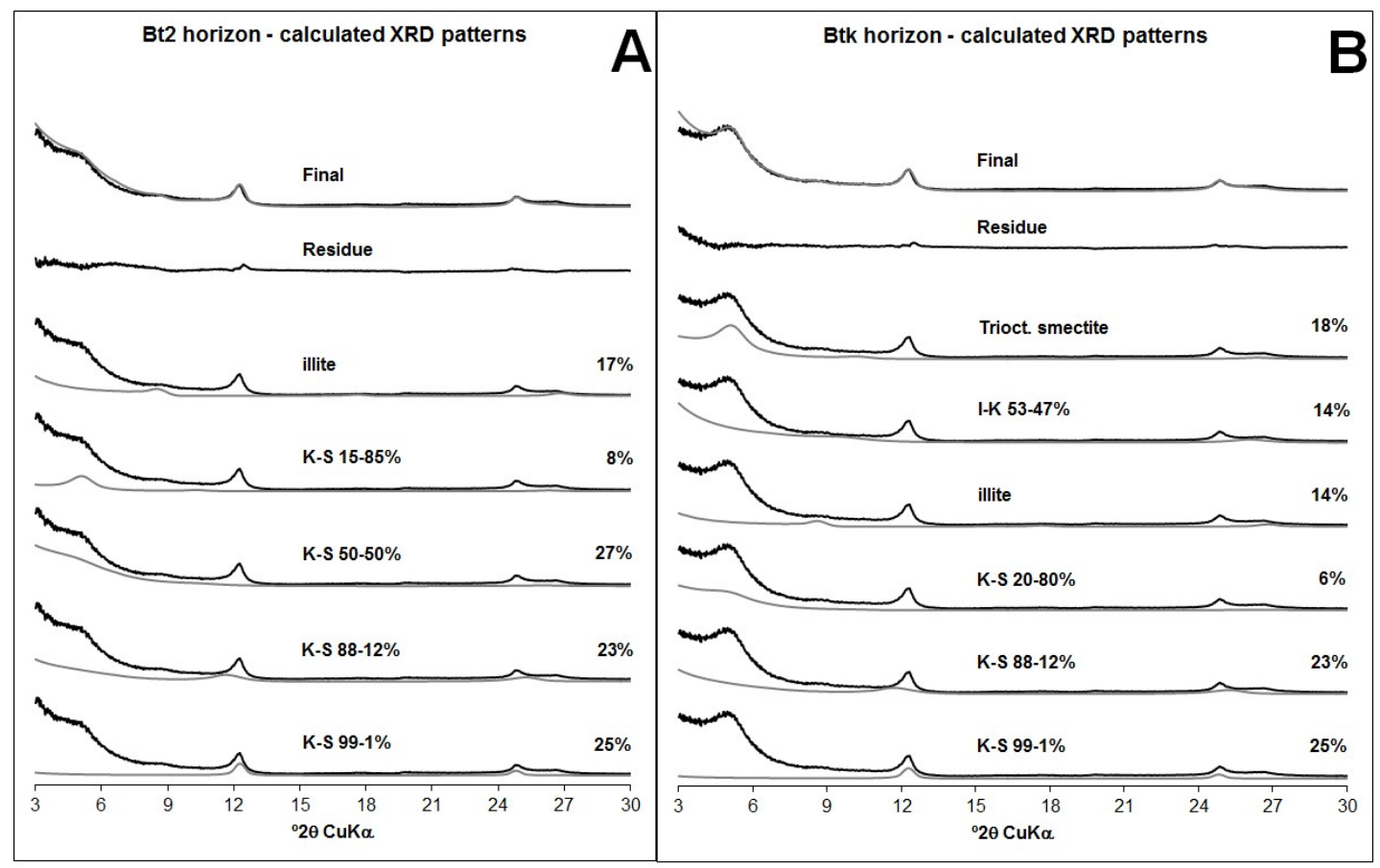

Figure 8. XRD modeling carried out with NEWMOD 3.2.1 for the glycolated oriented patterns. The individual calculated patterns (gray lines) for each mineral in the samples and the final calculated pattern are overlapped with the experimental pattern (black lines), together with their proportion in 
the samples. The residue is the difference between the experimental and final calculated pattern A experimental and calculated (black line) patterns for the $\mathrm{Bt} 2$ horizon sample. B - experimental and calculated patterns for the Btk horizon.

In the Bt2 horizon, a range of kaolinite-smectite (K-S) minerals was detected (Table 1), including kaolinite-rich K-S minerals (Figure 8A; minerals $1 \mathrm{~A}$ and $2 \mathrm{~A}$ in Table 1, with $99 \%$ and $88 \%$ of kaolinite layers, respectively) with large number of layers per coherent domain (Nmax and Nmean values) and high Fe octahedral content. The other K-S minerals have a higher content of smectite layers (3A and $4 \mathrm{~A}$, Table 1), reaching $50 \%$ and $85 \%$ of smectite layers, with very low Nmax and Nmean values. Kaolinite-rich to intermediate compositions prevail in quantitative terms $(23 \%$ to $27 \%$ ), while the smectite-rich K-S represents $8 \%$ of the clays. An illite endmember mineral was also detected, with low octahedral Fe content and intermediate Nmax and Nmean values. It represents $17 \%$ of the clays in the samples. Similar mineral composition was detected in the fine clay fraction of the Btk horizon (Figure 8B), but with important differences. The range of K-S minerals, from kaolinite-rich (Figure 8B; minerals 2A and 2B, Table 1) to smectite-rich K-S minerals (mineral 3B, Table 1) prevail, but the phase with intermediate compositions was not identified. The Nmax and Nmean values and octahedral Fe content for K-S minerals follow the same pattern described for the phases in the $\mathrm{Bt} 2$ horizon, i.e. high number of layers per coherent domains for kaolinite-rich phases and high values of octahedral $\mathrm{Fe}$ in smectite layers. The proportions of these kaolinite-rich K-S minerals are also dominant, comprising $47 \%$ of the clay minerals in the sample. However, the most remarkable difference of this sample is the existence of a trioctahedral smectite endmember, with low number of layers per coherent domains, high octahedral Fe content, representing $18 \%$ of the clays. Kaolinite-illite (K-I) was also detected (53\% of illite layers), representing $14 \%$ of the clay minerals.

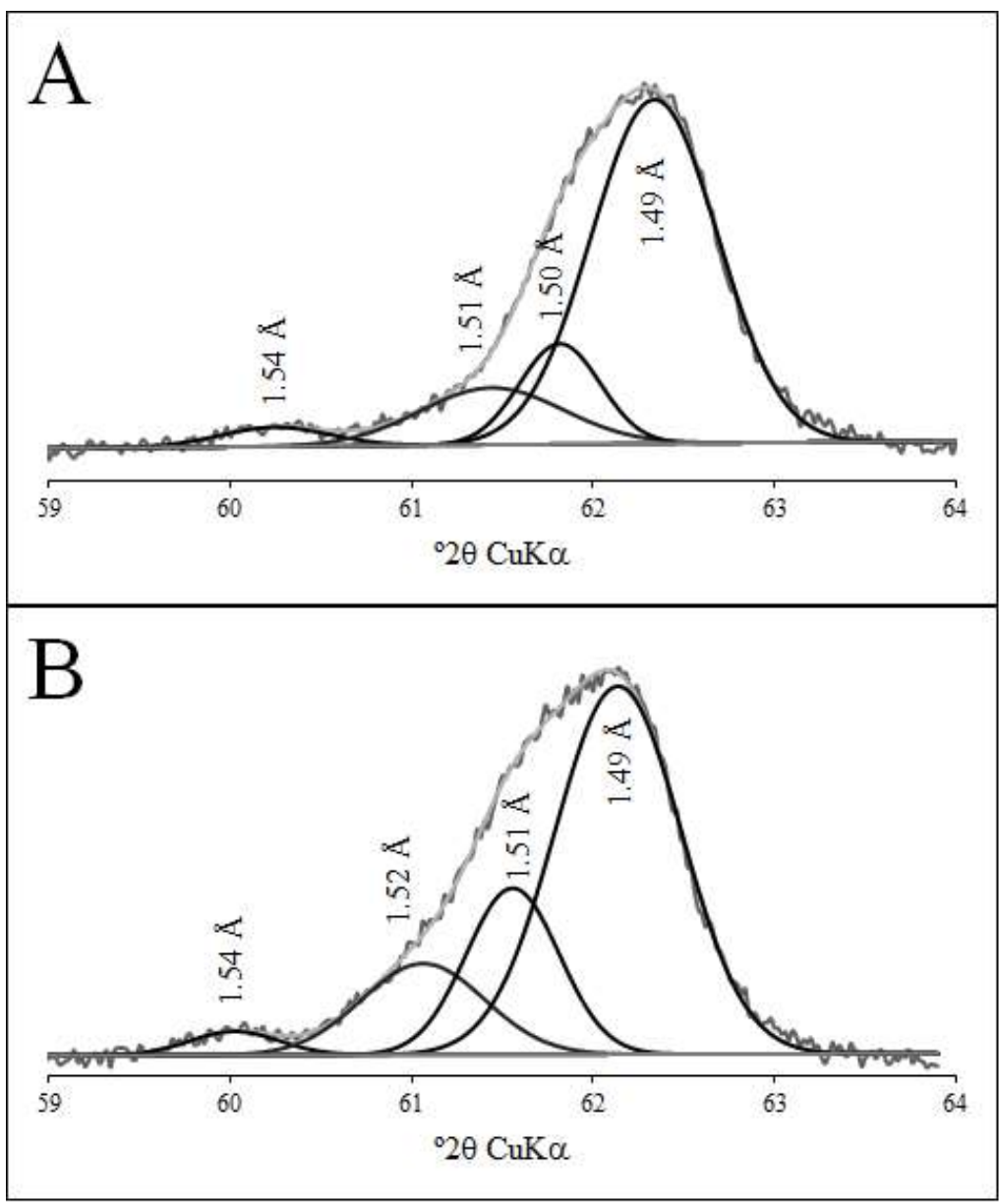

Figure 9. The experimental pattern of 060 region and peaks for Bt2 (A) and Btk (B) horizon. 
In Bt2 and Btk samples, the peak fitting procedure showed at least four peaks with maxima at different positions (Figures 9A, B). In the two samples, a peak at $1.54 \AA$ denoted the presence of quartz as an accessory component. In the Bt2 sample, peaks at $1.51 \AA$ and $1.50 \AA$ are assigned as $\mathrm{Fe}-$ rich component in illite layers and to Al-rich dioctahedral occupancy in 2:1 layers, respectively (Brindley \& Brown, 1980). These peaks correspond to $13 \%$ of the total calculated area. The dioctahedral component in kaolinite, with maximum at $1.49 \AA$, is the dominant component in this sample ( $70 \%$ of the area). In the Btk sample, four peaks were also detected, although some important differences are noticeable. The kaolinite dioctahedral component dominates the patterns as well $(62 \%$ of the curve area), and the proportion of Fe-rich octahedral component of illite layers increased (20\% of the area). However, the Al-rich occupancy associated with 2:1 clays disappear and are replaced by a peak with maxima at $1.52 \AA$, assigned to trioctahedral occupancy in smectite minerals (Furquim et al., 2008; Brindley and Brown, 1980). This last peak comprises approximately $15 \%$ of the calculated area.

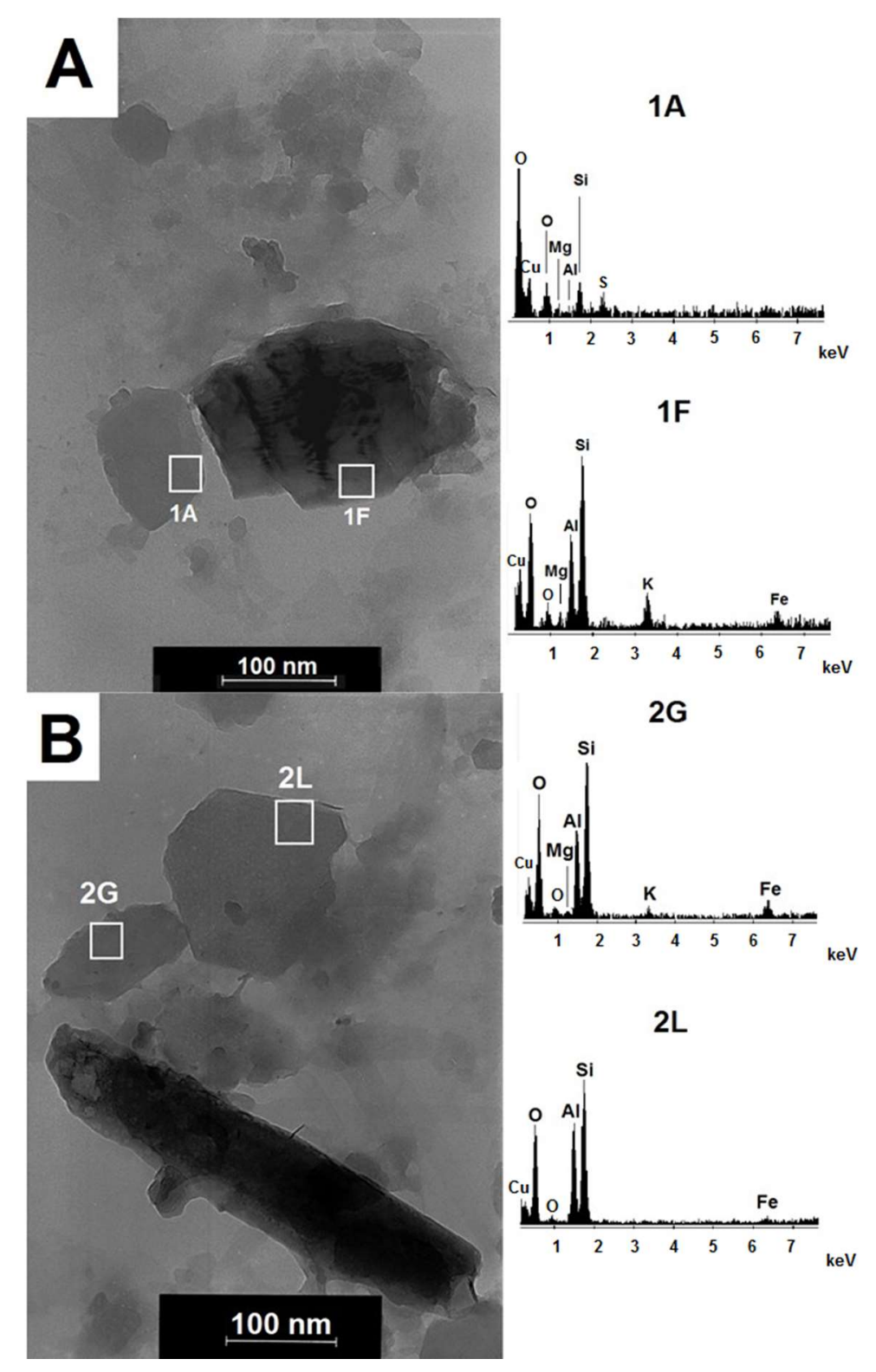

Figure 10. TEM images of clay crystals (referred in Table 2) and their respective EDS spectra. (A) Mg-rich smectitic crystal (1A) and a crystal with illite-like composition (1F), Btk horizon. (B) a kaolinitic crystal (2L) and a I/S crystal (2G), Bt2 horizon. The squared areas were analyzed for EDS spectra. 
Table 2. Chemical composition and calculated chemical formulas of the crystals investigated by TEM-EDS in the Btk and Bt2 horizon samples ${ }^{1}$.

\begin{tabular}{|c|c|c|c|c|c|c|c|c|c|c|c|c|c|c|c|c|c|c|c|c|}
\hline \multirow[t]{2}{*}{ Label } & \multirow[t]{2}{*}{ Min. type } & \multirow[t]{2}{*}{$\mathrm{SiO}_{2}$} & \multirow[t]{2}{*}{$\mathrm{Al}_{2} \mathbf{O}_{3}$} & \multirow[t]{2}{*}{$\mathrm{Fe}_{2} \mathrm{O}_{3}$} & \multirow{2}{*}{$\begin{array}{r}\text { MgO } \\
\text { wt. } \% \\
\end{array}$} & \multirow[t]{2}{*}{$\mathrm{K}_{2} \mathrm{O}$} & \multirow[t]{2}{*}{$\mathrm{CaO}$} & \multirow[t]{2}{*}{ Total } & \multicolumn{2}{|c|}{ TC } & \multicolumn{3}{|c|}{ OC } & \multicolumn{3}{|c|}{ IC } & \multirow[t]{2}{*}{ T Ch } & \multirow[t]{2}{*}{ O Ch } & \multirow[t]{2}{*}{ L Ch } & \multirow[t]{2}{*}{ I Ch } \\
\hline & & & & & & & & & $\mathbf{S i}^{4+}$ & $\mathbf{A} \mathbf{l}^{3+}$ & $\mathbf{A} \mathbf{l}^{3+}$ & $\mathrm{Fe}^{3+}$ & $\mathbf{M g}^{2+}$ & $\mathbf{K}^{+}$ & $\mathbf{M g}^{2+}$ & $\mathrm{Ca}^{2+}$ & & & & \\
\hline \multicolumn{21}{|c|}{ Btk horizon } \\
\hline 1A & $\mathbf{S}$ & 53.7 & 17.8 & 7.8 & 10.3 & 0.0 & 0.0 & 89.6 & 3.63 & 0.37 & 1.04 & 0.39 & 0.77 & 0.00 & 0.27 & 0.00 & -0.37 & -0.17 & -0.54 & 0.54 \\
\hline 1B & $\mathbf{S}$ & 53.2 & 24.5 & 6.8 & 4.7 & 0.0 & 0.0 & 89.3 & 3.56 & 0.44 & 1.49 & 0.34 & 0.17 & 0.00 & 0.30 & 0.00 & -0.44 & -0.17 & -0.60 & 0.60 \\
\hline $1 \mathrm{C}$ & $\mathbf{S}$ & 51.9 & 23.8 & 5.0 & 4.0 & 0.0 & 0.0 & 84.7 & 3.63 & 0.37 & 1.58 & 0.26 & 0.15 & 0.00 & 0.26 & 0.00 & -0.37 & -0.15 & -0.53 & 0.53 \\
\hline 1D & I & 56.7 & 21.1 & 4.1 & 2.5 & 6.7 & 0.0 & 91.0 & 3.82 & 0.18 & 1.49 & 0.21 & 0.30 & 0.58 & 0.05 & 0.00 & -0.18 & -0.30 & -0.48 & 0.48 \\
\hline $1 \mathrm{E}$ & $\mathbf{I} / \mathbf{S}$ & 56.7 & 25.7 & 3.9 & 2.0 & 3.0 & 0.0 & 91.3 & 3.71 & 0.29 & 1.69 & 0.19 & 0.12 & 0.25 & 0.08 & 0.00 & -0.29 & -0.12 & -0.41 & 0.41 \\
\hline $1 F$ & I & 55.1 & 25.4 & 4.0 & 1.7 & 4.1 & 0.0 & 90.4 & 3.67 & 0.33 & 1.68 & 0.20 & 0.12 & 0.35 & 0.05 & 0.00 & -0.33 & -0.12 & -0.45 & 0.45 \\
\hline $1 \mathrm{G}$ & K-S & 53.7 & 28.8 & 4.9 & 1.3 & 0.9 & 0.0 & 89.7 & 3.57 & 0.43 & 1.81 & 0.22 & 0.00 & 0.08 & 0.13 & 0.00 & -0.43 & 0.10 & -0.33 & 0.33 \\
\hline $1 \mathrm{H}$ & K-S & 56.1 & 28.6 & 4.4 & 1.2 & 0.0 & 0.0 & 90.2 & 3.64 & 0.36 & 1.83 & 0.21 & 0.00 & 0.00 & 0.12 & 0.00 & -0.36 & 0.13 & -0.23 & 0.23 \\
\hline 1I & K-S & 57.7 & 28.3 & 3.9 & 1.1 & 0.0 & 0.0 & 91.0 & 3.72 & 0.28 & 1.86 & 0.16 & 0.00 & 0.00 & 0.11 & 0.00 & -0.28 & 0.07 & -0.21 & 0.21 \\
\hline $\mathbf{1 J}$ & K-S & 55.8 & 31.9 & 3.4 & 1.0 & 0.4 & 0.0 & 92.5 & 3.54 & 0.46 & 1.92 & 0.16 & 0.00 & 0.03 & 0.09 & 0.00 & -0.46 & 0.24 & -0.22 & 0.22 \\
\hline $1 \mathrm{~K}$ & $\mathbf{K}$ & 54.7 & 31.6 & 3.6 & 0.0 & 0.0 & 0.0 & 89.9 & - & - & - & - & - & - & - & - & - & - & - & - \\
\hline $1 \mathrm{~L}$ & K & 53.9 & 28.6 & 2.1 & 0.0 & 0.6 & 2.2 & 87.4 & - & - & - & - & - & - & - & - & - & - & - & - \\
\hline \multirow[t]{2}{*}{$1 \mathrm{M}$} & K & 58.2 & 30.9 & 3.8 & 0.0 & 0.0 & 0.0 & 93.0 & - & - & - & - & - & - & - & - & - & - & - & - \\
\hline & & & & & & & & & - & - & - & - & - & - & - & - & - & - & - & - \\
\hline \multicolumn{21}{|c|}{ Bt2 horizon } \\
\hline $2 \mathrm{~A}$ & I & 48.1 & 15.8 & 15.7 & 3.6 & 5.2 & 0.0 & 93.53 & 3.52 & 0.48 & 0.88 & 0.86 & 0.26 & 0.49 & 0.13 & 0.00 & -0.48 & -0.26 & -0.74 & -0.74 \\
\hline 2B & $\mathbf{I} / \mathbf{S}$ & 54.1 & 17.4 & 12.2 & 3.2 & 4.5 & 0.0 & 91.40 & 3.71 & 0.29 & 1.12 & 0.63 & 0.25 & 0.39 & 0.07 & 0.00 & -0.29 & -0.25 & -0.54 & 0.54 \\
\hline $2 \mathrm{C}$ & I & 55.0 & 23.4 & 5.7 & 2.5 & 6.2 & 0.0 & 92.72 & 3.66 & 0.34 & 1.49 & 0.28 & 0.23 & 0.53 & 0.23 & 0.00 & -0.34 & -0.23 & -0.57 & 0.57 \\
\hline 2D & $\mathbf{I} / \mathbf{S}$ & 61.0 & 25.1 & 7.2 & 3.1 & 3.2 & 0.0 & 99.53 & 3.68 & 0.32 & 1.51 & 0.33 & 0.16 & 0.25 & 0.12 & 0.00 & -0.32 & -0.16 & -0.48 & 0.48 \\
\hline $2 E$ & I & 51.8 & 18.3 & 18.7 & 3.0 & 6.4 & 0.0 & 98.28 & 3.49 & 0.51 & 0.94 & 0.94 & 0.12 & 0.27 & 0.18 & 0.00 & -0.51 & -0.12 & -0.63 & 0.63 \\
\hline $2 F$ & I & 52.7 & 21.8 & 9.8 & 2.5 & 5.3 & 0.0 & 92.03 & 3.58 & 0.42 & 1.32 & 0.50 & 0.18 & 0.46 & 0.07 & 0.00 & -0.42 & 0.18 & -0.60 & 0.60 \\
\hline $2 G$ & $\mathbf{I} / \mathbf{S}$ & 53.4 & 25.0 & 7.7 & 2.4 & 3.5 & 0.0 & 92.02 & 3.55 & 0.45 & 1.51 & 0.38 & 0.11 & 0.30 & 0.13 & 0.00 & -0.45 & -0.11 & -0.56 & 0.56 \\
\hline $2 \mathrm{H}$ & $\mathbf{I} / \mathbf{S}$ & 58.5 & 22.2 & 14.4 & 2.1 & 3.3 & 0.0 & 102.00 & 3.62 & 0.38 & 1.24 & 0.67 & 0.09 & 0.26 & 0.10 & 0.00 & -0.38 & -0.09 & -0.47 & 0.47 \\
\hline 2I & $\mathbf{I} / \mathbf{S}$ & 56.8 & 22.8 & 7.4 & 1.9 & 2.6 & 0.0 & 91.54 & 3.75 & 0.25 & 1.52 & 0.37 & 0.11 & 0.22 & 0.07 & 0.00 & -0.25 & -0.11 & -0.36 & 0.36 \\
\hline 2J & K-S & 54.1 & 31.4 & 2.5 & 1.3 & 0.7 & 1.0 & 91.00 & 3.50 & 0.50 & 1.90 & 0.12 & 0.00 & 0.06 & 0.13 & 0.07 & -0.50 & 0.05 & -0.45 & 0.45 \\
\hline $2 K$ & $\mathbf{K}$ & 60.5 & 33.6 & 5.5 & 0.0 & 0.0 & 0.0 & 99.52 & - & - & - & - & - & - & - & - & - & - & - & - \\
\hline $2 \mathrm{~L}$ & $\mathbf{K}$ & 61.4 & 31.0 & 1.1 & 0.0 & 0.0 & 0.0 & 93.63 & - & - & - & - & - & - & - & - & - & - & - & - \\
\hline
\end{tabular}

$\mathrm{TC}$ - tetrahedral cations, per half formula unit $\left(\mathrm{O}_{10}[\mathrm{OH}]_{2}\right.$ basis $)$; OC - octahedral cations, per half formula unit; IC - interlayer cations, per half formula unit; $\mathrm{T}$ Ch - tetrahedral charge, per half formula unit; $\mathrm{O} \mathrm{Ch}$ - octahedral charge, per half formula unit; L Ch - layer charge, per half formula unit; I Ch - interlayer positive charge, per half formula unit 
Transmission electron microscopy with X-ray dispersive energy spectroscopy (TEM-EDS).

Transmission electron microscopy with X-ray dispersive energy spectroscopy data (Table 2, Figure 10) show the existence of mineral grains with different compositions, relatively similar to information provided by XRD modelling. Crystals assigned as kaolinitic have high $\mathrm{SiO}_{2}$ and $\mathrm{Al}_{2} \mathrm{O}_{3}$ contents, with $\mathrm{Fe}$ as minor component and no interlayer cations (crystals $1 \mathrm{~K}, 1 \mathrm{~L}$ and $1 \mathrm{M}$, Btk horizon; $2 \mathrm{~K}, 2 \mathrm{~L}, \mathrm{Bt} 2$ horizon - Table 2). In the two horizons, there are minerals with intermediate compositions between kaolinite and smectite, which fit into the composition of K-S minerals (Cuadros et al., 2009). These crystals have high $\mathrm{SiO}_{2} / \mathrm{Al}_{2} \mathrm{O}_{3}$ ratios, low to moderate layer charges (0.28 to -0.50 per half unit formula) and $\mathrm{Mg}$ as the main interlayer cation. The octahedral sheet is rich in $\mathrm{Al}$, with minor contents of $\mathrm{Mg}$ and $\mathrm{Fe}$, producing positive charges. These positive charges may not be realistic, because chemical formulas of K-S were normalized to a 2:1 structure composition and the excess of Al may be mostly attributed to kaolinite layers, although it is impossible to assess what fraction of $\mathrm{Al}$ belongs to kaolinite and smectite layers.

Smectite endmember compositions were assigned to three different crystals in the Btk horizon. They were not detected in the Bt2 horizon, in agreement with the XRD data. Crystals $1 \mathrm{~B}$ and $1 \mathrm{C}$ have moderate $\mathrm{Fe}_{2} \mathrm{O}_{3}$ and $\mathrm{MgO}$ contents, in low proportions in octahedral sites, or in the interlayer position in the case of $\mathrm{Mg}$. Crystal $1 \mathrm{~A}$, however, has distinct high $\mathrm{MgO}$ contents mostly attributed to octahedral sites, matching with the composition of trioctahedral smectite species (Newman and Brown, 1987; Furquim et al., 2008). There is a mismatch between Fe data obtained from XRD modelling procedure and TEM-EDS for smectite-like minerals, which can be explained by the effects produced by high $\mathrm{Fe}$ in the XRD patterns of clay minerals. NEWMOD software allows varying octahedral $\mathrm{Fe}$ content in the different clay minerals individually with good accuracy (Moore and Reynolds, 1997), but when several Fe-rich clays are mixed to yield a calculated pattern, the values may not match with chemical analyses (Cuadros et al., 2013). It seems to be the case for our samples, since the TEM-EDS data show lower proportions of $\mathrm{Fe}_{2} \mathrm{O}_{3}$ and a higher contribution of $\mathrm{MgO}$. The high number of clay phases with moderate/high Fe content likely affects the XRD modelling results and, therefore, the chemical results obtained from TEM-EDS are apparently more realistic.

The crystals with illite-like composition (assigned as I, in table 2) have moderate to high layer charges ( $\sim-0.5$ to -0.7 per half unit formula). They are characterized by moderate $\mathrm{K}_{2} \mathrm{O}$ content that balance most of the negative layer charge as interlayer cation. These layer charge values and $\mathrm{K}_{2} \mathrm{O}$ contents are lower than those described for standard illitic minerals (Newman and Brown, 1987), but some effects produced during EDS spectra acquisition, like alkali loss (Van Der Pluijm, 1988; Cuadros et al., 2009) and even the particle overlapping, which may have reduced these contents. The $\mathrm{Al}_{2} \mathrm{O}_{3}$ contents are distributed in tetrahedral and octahedral sites, accompanied by high $\mathrm{Fe}_{2} \mathrm{O}_{3}$ content that occupies large proportions of octahedral sites. The $\mathrm{MgO}$ is distributed in octahedral and interlayer sites, producing moderate octahedral charge and balancing the layer charge (together with $\mathrm{K}$ ).

The other crystals with moderate $\mathrm{K}_{2} \mathrm{O}$ contents have a similar chemical composition of those assigned as I, but the calculated layer charges are lower, in the typical range of smectite end member minerals ( -0.4 to -0.5 per half formula unit). On the other hand, smectite group minerals do not allow such high $\mathrm{K}_{2} \mathrm{O}$ values (Newman and Brown, 1987). Since vermiculite and I-S were not detected in the XRD patterns, which could correspond to this composition, it is impossible to be precise about whether these minerals are illite end members or the effects mentioned in the previous paragraph were maximized. In this case, smectite-like crystals could have affected their chemical composition, reducing the $\mathrm{K}_{2} \mathrm{O}$ contents, or the alkali loss was higher during data acquisition. In any case, they are assigned as I/S in Table 2, enhancing the likely influence of smectite minerals in illitic crystals.

\section{Discussion}

\section{Soluble salt accumulation and minerals formation under alkaline conditions}

The water chemistry of the São Lourenço River is quite similar to that of rivers originating from sandstone exposed on the whole eastern border of the Pantanal (Rezende Filho et al., 2012, 2015). On the one hand they are low mineralized waters, i.e., able to favor the elimination of any soluble salts in good drainage conditions. On the other hand, these waters exhibit a positive $\mathrm{RA}_{\text {calcite }}(\mathrm{Alk}>$ 
$\mathrm{Ca}^{2+}$ ) and follow an alkaline pathway in the case of evapoconcentration (Al-Droubi et al., 1980, Barbiero et al., 2004). Figure 4 shows the soil solutions along the trench are more concentrated, but consistent with the river chemistry, suggesting the São Lourenço River imposed its chemical alkaline pathway onto the soils of the trench (Oliveira Junior et al., 2019). After successive floods and evaporation events, calcite saturation is reached, resulting in an increase of alkalinity with evapoconcentration (Barbiero et al., 2008). However, since part of the alkalinity is withdrawn from solution for calcite precipitation, the alkalinity increases slightly less than the concentration factor. In this chemical context, $\mathrm{Ca}$ is controlled at a low level, with a trend to decrease during evapoconcentration as observed for the most saline extracts (Figure 4). Magnesium is generally poorly incorporated in calcite at maximum cation proportion of about 5\% (Barbiero et al., 2008). However alkaline solutions favor the formation of Mg-rich silicates, generally as trioctahedral Mgsmectite (Furquim et al., 2008; Deocampo, 2015; Humphries et al., 2010). As a result, the Mg in solution is also controlled at a low level and shows a tendency to decrease in the most concentrated solutions. Consequently, while the most diluted soil solutions have a bicarbonate $\left(\mathrm{HCO}_{3}\right) / \mathrm{Na}-\mathrm{Ca}$ chemical profile, $\mathrm{Na}$ quickly becomes the dominant cation during the concentration and the chemical profile changes to $\mathrm{HCO}_{3} / \mathrm{Na}$. For the most concentrated solutions, the $\mathrm{Na}: \mathrm{Ca}$ ratio is close to 70, favoring solonization. Thus, because of the adsorption of part of the $\mathrm{Na}$ on the soil complex, the above-defined estimate of $\mathrm{CF}$ in equation (1) is probably a slight underestimate of the actual concentration factor, although this has no impact on the interpretation proposed here. The occurrence of trioctahedral $\mathrm{Mg}$-smectite in the Btk horizon is confirmed by the decomposition of the 060 region peaks of the randomly-oriented XRD patterns (Figure 9B), and the chemical analysis of individual crystals by TEM-EDS with high MgO levels (Table 2).

\section{Current processes of mineral transformations}

Electromagnetic induction measurements indicate that the highest ECa values are in the paleolevee (Figure 2A) and that the abrupt transition matches with the limit of influence of the seasonal floods. It suggests a current tendency towards dilution and elimination of soluble salts in the lower grounds, whereas more alkaline conditions maintain in higher grounds, and this for these two reasons: first, higher grounds are not reached by the flooding waters, and second, the solodization induced a decrease in the structural stability and soil permeability (observed in the Btk horizon) preventing from rainwater flow through the soil at higher grounds (Oliveira Junior et al., 2019).

Transformation of smectite into kaolinite by interstratification is a progressive, multi-step process involving several changes in mineral lattices (Dudek et al., 2006; Humphries et al., 2010; Ryan and Huertas, 2009), including : (1) the gradual removal of one tetrahedral sheet from 2:1 layers, followed by proton fixation on the octahedral apical position; (2) the replacement of $\mathrm{Mg}^{2+}$ by $\mathrm{Al}^{3+}$ in the octahedral sites; (3) the oxidation of residual octahedral $\mathrm{Fe}^{2+}$ in the $2: 1$ structure; and (4) the formation of kaolinite patches with partial collapse of smectite layers to a $7 \AA$ structure. The existence of K-I mineral in Bt2 samples may result from a similar process, but involving the direct transformation of illite into kaolinite, which has already been described in other Brazilian soils, but in more intense weathering conditions (Andrade et al., 2019). In this case, K removal from interlayer positions may take place from the edge of layers before the transformation advances.

Despite the high concentration of waters in the Btk horizon, at the upper parts of the paleolevee, the presence of K-S phases with intermediate smectite content suggests a current condition that induce a partial transformation of trioctahedral smectite into dioctahedral phases, likely by a solid-state reactional mechanism in which Mg-rich trioctahedral sites are progressively transformed into Al-rich dioctahedral sites (Aldega et al., 2009). The flooding does not reach the Btk horizon currently and this effect cannot be addressed as the main cause of such transformation, as in the more acidified Bt2 horizon. However, considering the alkalized Btk horizon was formed in past semiarid conditions (McGlue et al., 2012; Oliveira Junior et al. 2019), the circulation of rainwater and the lower current evapotranspitarion rates (compared to past conditions) may trigger the transformation, which seems to be at initial stage. It does not change the role of flooding as the main driver of mineral 
transformation in the studied soil system because the degree of kaolinization is remarkably high in the $\mathrm{Bt} 2$ horizon, where acidification and leaching are more intense.

The existence of several interstratified clays with intermediate compositions suggests the crystalchemical changes are progressive, without lattice disruption and re-precipitation of the soluble products as new endmember clays. On the contrary, they produce intermediary products represented by the interstratified K-S minerals (Ryan and Huertas, 2009), resulting from the sequential crystalchemical changes induced by the new geochemical conditions induced by acidic waters. These changes start from the transition of trioctahedral towards dioctahedral structures (Deocampo et al., 2009), visible in the Btk horizon that undergoes a slight acidification. In the more acidified Bt2 horizon, this transition is apparently complete, since the trioctahedral smectite endmember was not detected (Figure 9B) and the reaction involves only dioctahedral structures (dioctahedral to kaolinite via $\mathrm{K}-\mathrm{S})$.

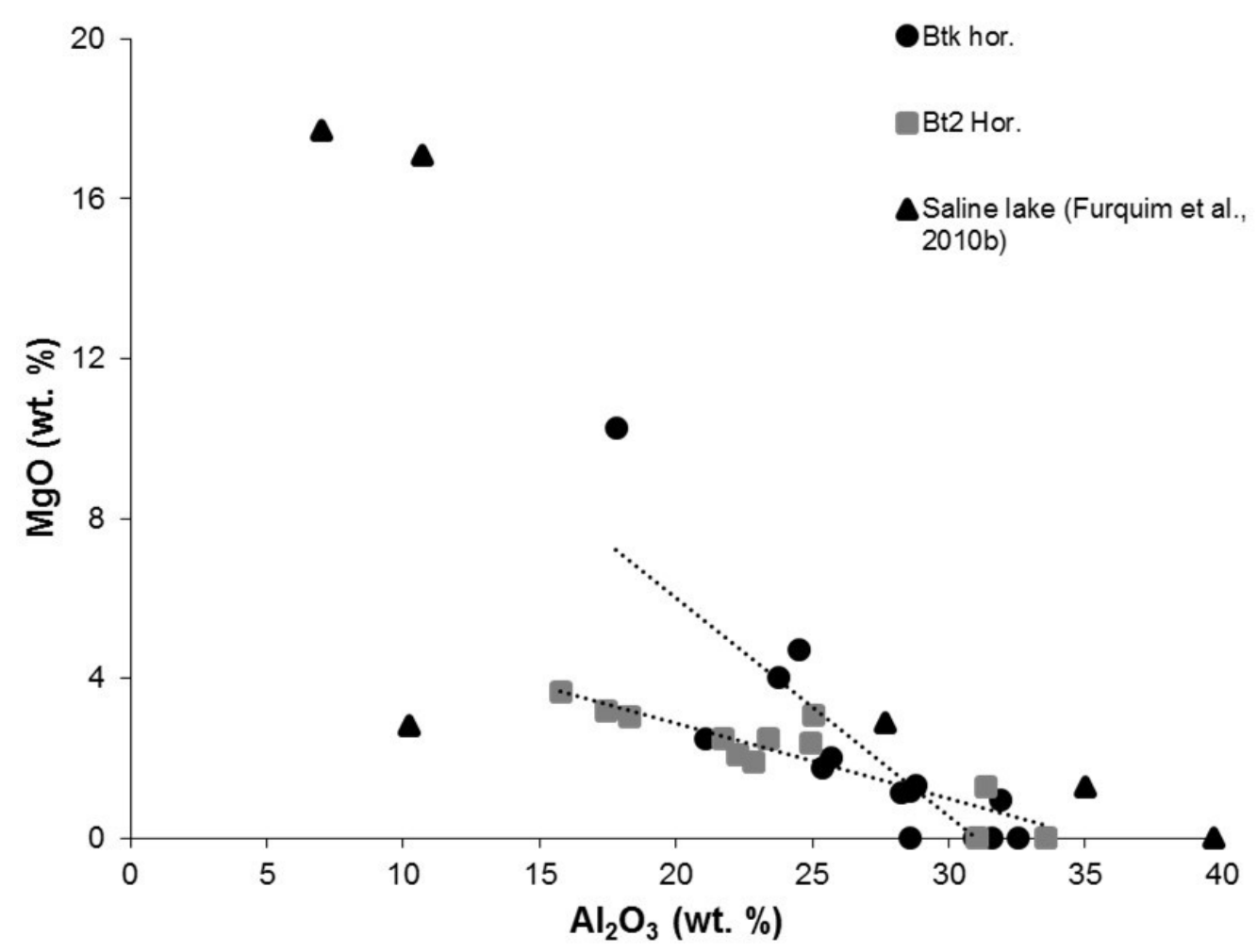

Figure 11. Correlation of the levels of $\mathrm{Al}_{2} \mathrm{O}_{3} v s \mathrm{MgO}$ (wt\%) obtained by TEM-EDS on the K, K-S, and $\mathrm{S}$ crystals for Btk, Bt2 and Furquim et al. (2010b) data.

The chemical evolution of clay minerals by this mechanism is more evident by comparing TEMEDS results of the two studied horizons to data from Furquim et al. (2010b) in a soil system in southern Pantanal under current influence of alkaline waters from a soda lake (Figure 11). Under such conditions (where the surface horizon is located at the border of the lake) trioctahedral smectite crystals with very high $\mathrm{MgO}$ content (up to $17.7 \%$. wt \%) were detected, assumed as one of the mineral products of soil alkalization.

In our samples, one Mg-rich smectite crystal in the Btk horizon was also, but containing less $\mathrm{MgO}(\sim 10 \%$, wt. $\%$, Table 2$)$. The existence of $\mathrm{Mg}$-rich trioctahedral smectite in the Btk horizon enhances the influence of water alkalinity, but the lower $\mathrm{MgO}$ contents (compared to crystals described by Furquim et al., 2010b) suggests Mg depletion is taking place at current conditions, as a result of a slight but progressive acidification of Btk horizon (the $\mathrm{pH}$ values are close to 9.0, while in the alkaline soil system studied by the mentioned authors, the values are higher than 10). This is likely one of the first steps of the gradual chemical changes in clay mineral lattices, evidenced by the linear 
trends observed for crystals from Btk $\left(\mathrm{R}^{2}=0.72, \mathrm{p}<0.05\right)$ and $\mathrm{Bt}$ horizons $\left(\mathrm{R}^{2}=0.81, \mathrm{p}<0.05\right)$. The chemical composition of clay crystals range towards an enrichment of $\mathrm{Al}$, in agreement with the sequential transformation proposed to explain the increase of dioctahedral phases in the most acidified horizon, represented by the several K-S minerals detected by the XRD modelling procedure (Cuadros et al., 2009).

\section{Conclusions}

Geochemical and mineralogical data collected on the alkaline sodic soils of northern Pantanal in Brazil converge on the existence of an ancient system, formed by evapoconcentration of soil solutions whose chemical profile was imposed by the chemistry of the São Lourenço River, that still floods this region today. The concentration of soil solutions, which occurred in a geochemical context of positive $\mathrm{RA}_{\text {calcite, }}$ led to high $\mathrm{pH}$ values and sodization of the exchange complex probably in a drier past period or a dryer pedoclimate. Currently, the soluble salts are flushed by the flooding cycles and maintained only in the higher parts of the landscape (paleolevee / paleochannel). The evolution of mineral assemblage of soils is in agreement with these geochemical changes: trioctahedral Mg-rich smectite transforms into dioctahedral smectite, and then into kaolinite as soil solution becomes more acidic. Such transformation involves progressive crystal-chemical changes in clay minerals, resulting in a range of interstratified K-S minerals with gradual increase in the proportion of kaolinite layers. These transitional compositions in soil clays can be understood as records of environmental changes, since the mineral reactions proposed depend on a combination of climate/geomorphological modifications during Holocene towards a less alkaline soil solution.

\section{Acknowledgments}

We thank the SESC Pantanal for the logistical support. This work was supported by the São Paulo Research Foundation (FAPESP $n^{\circ}$ 09/54372-0, 11/11905-9, 11/13924-0 and 13/09192-0) and by the National Council of Technological and Scientific Development ( CNPq 201049/2012-0), and by the National Institute of Sciences of the Universe (Ec2co-INSU). L. Barbiero was supported by grants from the FAPESP (n 17/23301-7), the Consulate of France in São Paulo, and the São Carlos Federal University in Sorocaba (UFSCar). Jim Hesson edited the manuscript (https://academicenglishsolutions.com). We also thanks Prof. Vincent Valles, Hydrogeology Department, Université d'Avignon, for geochemical modelling.

Data Sharing: The data that support the findings of this study are available from the corresponding author upon reasonable request.

\section{References}

Aldega, L., Cuadros, J., Laurora, A., \& Rossi, A. 2009. Weathering of phlogopite to beidellite in a karstic environment. American Journal of Science, 309, 689-710, doi: 10.2475/08.2009.03

Al-Droubi, A., Fritz, B., Gac, J.Y. \& Tardy, Y. 1980. Generalized residual alkalinity concept; application to prediction of the chemical evolution of natural waters by evaporation. American Journal of Science, 280, 560-572.

Andrade, G.R.P., Azevedo, A.C., Lepchak, J.K., Assis, T.C., 2019. Weathering of Permian sedimentary rocks and soil clay minerals transformations under subtropical climate, southern Brazil (Paraná State). Geoderma 336, 31-48, doi:10.1016/j.geoderma.2018.08.026

Armenteros, I., Angeles Bustillo, M.A. \& Blanco, J.A. 1995. Pedogenic and groundwater processes in a closed Miocene basin (northern Spain). Sedimentary Geology, 99, 17-36, doi:10.1016/00370738(95)00002-P

Assine, M.L. \& Soares, P.C. 2004. Quaternary of the Pantanal, West-central Brazil. Quaternary International, 114, 23-34, doi: 10.1016/S1040-6182(03)00039-9

Barbiero, L., Valles, V., Cheverry, C. 2004 - Reply to the comment - Some observations with respect to sodicity hazard of irrigation waters, by Van Hoorn, J.W. Agricultural water Management 68, 177-184, doi:10.1016/j.agwat.2004.03.011 
Barbiero, L., Berger, G., Rezende Filho, A.T., Meunier, J.-F., Martins-Silva, E.R. \& Furian, S. 2016. Organic Control of Dioctahedral and Trioctahedral Clay Formation in an Alkaline Soil System in the Pantanal Wetland of Nhecolândia, Brazil (G Yang, Ed.). PLOS ONE, 11, e0159972, , doi:10.1371/journal.pone.0159972

Barbiero, L., Filho, A.R., Furquim, S.A.C., Furian, S., Sakamoto, A.Y., Valles, V., Graham, R.C., Fort, M., Ferreira, R.P.D. \& Neto, J.P.Q. 2008. Soil morphological control on saline and freshwater lake hydrogeochemistry in the Pantanal of Nhecolândia, Brazil. Geoderma, 148, 91-106, doi:10.1016/j.geoderma.2008.09.010.

Brindley, G.W. \& Brown, G. (Eds). 1980. Crystal Structures of Clay Minerals and their X-Ray Identification. Mineralogical Society of Great Britain and Ireland, Colchester and London.

Coelho, I.P. 2016. Do barro ao bamburro: relações entre a paisagem e a distribuição local de mamíferos e aves no Pantanal, Brasil. UFRGS. (At: http://hdl.handle.net/10183/150709. Accessed: 17/5/2018).

Cuadros, J., Nieto, F., Wing-Dudek, T. (2009) Crystal-chemical changes of kaolinite-smectite mixedlayer with progressive kaolinization, as investigated by TEM-AEM and HRTEM. Clay. Clay Miner. 57:742-750, doi: 10.1346/CCMN.2009.0570607

Deocampo, D.M. 2005. Evaporative evolution of surface waters and the role of aqueous CO2 in magnesium silicate precipitation: Lake Eyasi and Ngorongoro Crater, northern Tanzania. South African Journal of Geology, 108, 493-504, doi:10.2113/108.4.493.

Deocampo, D.M. 2015. Authigenic clay minerals in lacustrine mudstones. pp. 49-64, doi:10.2475/09.2009.03.

Deocampo, D.M., Cuadros, J., Wing-Dudek, T., Olives, J. \& Amouric, M. 2009. Saline lake diagenesis as revealed by coupled mineralogy and geochemistry of multiple ultrfine clay phases: Pliocene Olduvai Gorge, Tanzania. American Journal of Science, 309, 834-868.

Dudek, T., Cuadros, J. \& Fiore, S. 2006. Interstratified kaolinite-smectite: Nature of the layers and mechanism of smectite kaolinization. American Mineralogist, 91, 159-170, doi:10.2138/am.2006.1897.

Furquim, S.A.C., Barbiero, L., Graham, R.C., de Queiroz Neto, J.P., Ferreira, R.P.D. \& Furian, S. 2010a. Neoformation of micas in soils surrounding an alkaline-saline lake of Pantanal wetland, Brazil. Geoderma, 158, 331-342, doi:10.1016/j.geoderma.2010.05.015.

Furquim, S.A.C., Graham, R.C., Barbiero, L., de Queiroz Neto, J.P. \& Vallès, V. 2008. Mineralogy and genesis of smectites in an alkaline-saline environment of Pantanal wetland, Brazil. Clays and Clay Minerals, 56, 579-595, doi:10.1346/CCMN.2008.0560511.

Furquim, S.A.C., Graham, R.C., Barbiero, L., Queiroz Neto, J.P. \& Vidal-Torrado, P. 2010b. Soil mineral genesis and distribution in a saline lake landscape of the Pantanal Wetland, Brazil. Geoderma, 154, 518-528, doi:10.1016/j.geoderma.2009.03.014

Girard P, Fantin-Cruz I, Oliveira SML, Hamilton SK. 2010. Small-scale spatial variation of inundation dynamics in a floodplain of the Pantanal (Brazil). Hydrobiologia. , 638: 223-233, doi:10.1007/s10750-009-0046-9.

Graham, R.C. \& O'Geen, A.T. 2010. Soil mineralogy trends in California landscapes. Geoderma, 154, 418-437, doi:10.1016/j.geoderma.2009.05.018.

Humphries, M.S., Kindness, A., Ellery, W.N. \& Hughes, J.C. 2010. Sediment geochemistry, mineral precipitation and clay neoformation on the Mkuze River floodplain, South Africa. Geoderma, 157, 15-26, doi:10.1016/j.geoderma.2010.03.010.

Joeckel, R.M. \& Ang Clement, B.J. 2005. Soils, surficial geology, and geomicrobiology of salinesodic wetlands, North Platte River Valley, Nebraska, USA. Catena, 61, 63-101, doi:10.1016/j.catena.2004.12.006.

Junk, W.J., Piedade, M.T.F., Lourival, R., Wittmann, F., Kandus, P., Lacerda, L.D., Bozelli, R.L., Esteves, F.A., Nunes da Cunha, C., Maltchik, L., Schöngart, J., Schaeffer-Novelli, Y. \& Agostinho, A.A. 2014. Brazilian wetlands: their definition, delineation, and classification for research, sustainable management, and protection. Aquatic Conservation: Marine and Freshwater Ecosystems, 24, 5-22, doi:10.1002/aqc.2386. 
Lee, B.D., Graham, R.C., Laurent, T.E. \& Amrhein, C. 2004. Pedogenesis in a wetland meadow and surrounding serpentinitic landslide terrain, northern California, USA. Geoderma, 118, 303-320, doi:10.1016/S0016-7061(03)00214-3.

McGlue, M.M., Silva, A., Zani, H., Corradini, F.A., Parolin, M., Abel, E.J., Cohen, A.S., Assine, M.L., Ellis, G.S., Trees, M.A., Kuerten, S., Gradella, F. dos S. \& Rasbold, G.G. 2012. Lacustrine records of Holocene flood pulse dynamics in the Upper Paraguay River watershed. Quaternary Research. 78, 285-294, doi:10.1016/j.yqres.2012.05.015.

Nascimento, A.F., Furquim, S.A.C., Couto, E.G., Beirigo, R.M., Oliveira Junior, J.C., de Camargo, P.B. \& Vidal-Torrado, P. 2013. Genesis of textural contrasts in subsurface soil horizons in the Northern Pantanal-Brazil. Revista Brasileira de Ciência do Solo, 37, 1113-1127, doi:10.1590/S0100-06832013000500001.

Nascimento, A.F., Furquim, S.A.C., Graham, R.C., Beirigo, R.M., Oliveira Junior, J.C., Couto, E.G. \& Vidal-Torrado, P. 2015. Pedogenesis in a Pleistocene fluvial system of the Northern Pantanal Brazil. Geoderma, 255-256, 58-72, doi:10.1016/j.geoderma.2015.04.025.

Newman A.C.D., Brown G. (1987) The Chemical Constitution of Clays. In: Newman ACD (Ed.) Chemistry of Clays and Clay Minerals (Mineralogical Society Monograph No. 6). Longman Scientific \& Technical, London, pp 1-128.

Oliveira Junior, J.C., Beirigo, R.M., Chiapini, M., do Nascimento, A.F., Couto, E.G. \& VidalTorrado, P. 2017a. Origin of mounds in the Pantanal wetlands: An integrated approach between geomorphology, pedogenesis, ecology and soil micromorphology. PLOS ONE, 12, e0179197, doi:10.1371/journal.pone.0179197.

Oliveira Junior, J.C., Chiapini, M., Nascimento, A.F. do, Couto, E.G., Beirigo, R.M. \& VidalTorrado, P. 2017b. Genesis and Classification of Sodic Soils in the Northern Pantanal. Revista Brasileira de Ciência do Solo, 41, doi: 10.1590/18069657rbcs20170015.

Oliveira Junior, J.C., Furquim, S.A.C., Nascimento, A.F., Beirigo, R.M., Barbiero, L., Valles, V., Couto, E.G. \& Vidal-Torrado, P. Salt-affected soils on elevated landforms of an alluvial megafan, northern Pantanal, Brazil. 2019. Catena, 172, 819-830, doi:10.1016/j.catena.2018.09.041.

Oliveira Junior, J.C., de Freitas Melo, V., de Paula Souza, L.C. \& da Rocha, H.O. 2014. Terrain attributes and spatial distribution of soil mineralogical attributes. Geoderma, 213, 214-225, doi:10.1016/j.geoderma.2013.08.020.

Pal, D.K. 2017. Clay and Other Minerals in Soils and Sediments as Evidence of Climate Change. In: A Treatise of Indian and Tropical Soils, pp. 115-125. Springer International Publishing, Cham.

Pansu, M. \& Gautheyrou, J. 2006. Handbook of soil analysis: Mineralogical, organic and inorganic methods. Springer Berlin Heidelberg, Berlin, Heidelberg.

Por, F.D. 1995. The Pantanal of Mato Grosso (Brazil). Springer Netherlands, Dordrecht.

Reid, R.J. \& Mosley, L.M. 2016. Comparative contributions of solution geochemistry, microbial metabolism and aquatic photosynthesis to the development of high $\mathrm{pH}$ in ephemeral wetlands in South East Australia. Science of the Total Environment, 542, 334-343, doi:10.1016/j.scitotenv.2015.10.040.

Reynolds, R.C. Jr.; Reynolds, R.C. III., 1996. NEWMOD II, a Computer Program for the Calculation of the Basal Diffraction Intensities of Mixed-Layered Clay Mineral: R.C. Reynolds, 8 Brook Rd., Hanover NH.

Rezende Filho, A.T., Furian, S., Victoria, R.L., Mascré, C., Valles, V. \& Barbiero, L. 2012. Hydrochemical variability at the upper paraguay basin and pantanal wetland. Hydrology and Earth System Sciences, 16, 2723-2737, doi:10.5194/hess-16-2723-2012.

Rezende-Filho, A.T., Valles V., Furian S., Ouardi, J., Oliveira, C.M.S.C., Barbiero, L. 2015. Largescale mapping of lithological and anthropogenic factors affecting water chemistry in the upper Paraguay Basin. Journal of Environmental Quality 44, 1832-1842, doi:10.2134/jeq2015.01.0019.

Ryan, P.C. \& Huertas, F.J. 2009. The temporal evolution of pedogenic Fe-smectite to Fe-kaolin via interstratified kaolin-smectite in a moist tropical soil chronosequence. Geoderma, 151, 1-15, doi:10.1016/j.geoderma.2009.03.010. 
Shoba, V.N. \& Sen'kov, A.A. 2011. Equilibrium composition and properties of soil solutions. Eurasian Soil Science, 44, 1068-1076, doi:10.1134/S1064229311100139. 